\title{
Journey to Dialogue: Sisters of Our Lady of Sion and the Writing of Nostra Aetate ${ }^{1}$
}

\author{
CELIA DEUTSCH \\ cdeutsch@barnard.edu \\ Barnard College, New York, NY 10027
}

Introduction

Accounts of the preparation and promulgation of Nostra Aetate paragraph 4 on Oct. 28, 1965, focus entirely on men. In actual fact, the production of Nostra Aetate was the result of decades of encounter and collaboration among lay and clergy, men and women, Protestants, Catholics and Jews, as well as some Orthodox Christians in a variety of formal and informal contexts, particularly in

\footnotetext{
${ }^{1}$ This article is based on a talk first given for "Women Transforming Religion and Society," a course led by Professor Mary Boys (Dean of Academic Affairs, Union Theological Seminary, NYC) and Professor Shuly Rubin Schwartz (Dean of Undergraduate and Graduate Studies, Jewish Theological Seminary, NYC), at Union Theological Seminary, April 22, 2015; the material was then given in a paper ("The Sisters of Our Lady of Sion and the Writing of Nostra Aetate") for "The Role of Women in the Development and Implementation of Nostra Aetate, " a workshop of the Annual Conference of the International Council of Christians and Jews, Rome, June 29, 2015. I would like to thank Céline Hirsch Poynard, the archivist of the Congregation of Our Lady of Sion for making available archival materials. Thanks are also due Sr. Margaret Shepherd, n.d.s. who made available material from the Sion Centre for Dialogue and Encounter in London, and Emma Green, managing editor of The Atlantic.co, who generously shared documents with me. On the role of the sisters in the writing of Nostra Aetate, see Emma Green, "Developing Dialogue: the Congregation of Our Lady of Sion and Nostra Aetate, 1945-1969," Ecumenical Trends 41(February, 2012), 8/24-15/31; "Sisters of Sion: the Nuns Who Opened Their Doors for Europe's Jews," The Atlantic.com, October 11, 2012, http://www.theatlantic.com/international/archive/2012/10/sisters-of-sion-the-nuns-who-opened-theirdoors-for-europes-jews/263525/ (accessed Jan. 2, 2016); Sr. Marie-Bénédicte Salmon, n.d.s., "La Congrégation Notre-Dame de Sion en France; Pendant le Concile Vatican II," Sens 271(2002): $472-$ 487; Sr. Marie-Dominique Gros, "La congrégation Notre-Dame de Sion avant et après le concile Vatican II," Sens 271(2002): 488-503. On the development of Sisters' understanding of the Congregation's vocation, see Charlotte Klein, "From Conversion to Dialogue - the Sisters of Sion and the Jews: a Paradigm of Catholic-Jewish Relations?" Journal of Ecumenical Studies 18(1981): 388-400; Mary C. Boys, "The Sisters of Sion: From a Conversionist Stance to a Dialogical Way of Life," Journal of Ecumenical Studies 31(1994): 27-48; Madeleine Comte, "De la conversion à la rencontre; les religieuses de Notre-Dame de Sion (1843-1986)," Archives Juives 35 (2002): 102-119; Olivier Rota, "Une double fidélité. Évolution générale de la Congrégation des religieuses de Notre-Dame de Sion dans sa relations aux Juifs (1946-1969)," Sens 274 (2005): 67-77; Paule Berger Marx, Les relations entre les juifs et les catholiques dans la France de l'après-guerre 1945-1965 (Paris: Éditions Parole et Silence, 2009), 47-77.
} 
continental Europe, Great Britain and the United States. ${ }^{2}$ As Thomas Stransky, a member of the original Secretariat for Promoting Christian Unity, notes, the boundaries of these groups were permeable with participants sharing research and insights through their publications as well as in face-to-face encounters. ${ }^{3}$ The Sisters of Our Lady of Sion contributed to these developing Jewish-Christian relations.

Founded by Theodore Ratisbonne in 1847, the Sisters of Our Lady of Sion, or simply, the Sisters of Sion, are a Roman Catholic religious institute. ${ }^{4}$ Its original commitment to the Jewish people was usually expressed by praying for the Jews" "salvation," "regeneration," or "conversion." Active ministry principally involved education, often in places with large Jewish populations. Schools directed by the sisters welcomed Jews, Muslims, Orthodox and Protestant Christians. Sisters also worked with poor Jews from Russia and eastern Europe and, later, from North Africa. Though zealous in his desire for converts, Theodore Ratisbonne forbade the sisters in the strictest terms to proselytize, something exceptional in the nineteenth century when various missionary groups engaged in what François Delpech calls "unbridled proselytism” (un prosélytisme effréné). ${ }^{6}$

2 See Stransky's remarks in Nelson H. Minnich, Eugene J. Fisher, Thomas Stransky, Susannah Heschel, Alberto Melloni, and John Connelly, "Forum Essay," Catholic Historical Review 98 (2012): 758-759. On the Central European circle, see John Connelly, From Enemy to Brother; the Revolution in Catholic Teaching on the Jews, 1933-1965 (Cambridge MA: Harvard University Press, 2012). On French circles see Brenna Moore, "Philosemitism Under a Darkening Sky: Judaism in the French Catholic Revival," Catholic Historical Review 99 (2013): 262-297; “A Current of Catholic Renewal: the Roots of Vatican II and the Context for Thinking Judaism Anew"(paper presented at the Columbia University Seminar on Catholicism, Culture and Modernity, New York, NY, Dec. 2, 2014); and Catherine Poujol, Aimé Pallière (1868-1949); un chrétien dans le judaïsme (Paris: Desclée de Brouwer, 2003), esp. 286-311.

${ }^{3}$ Minnich et al., "Forum Essay," 758-65.

4 "Religious institute" is an expression used in the 1983 revision of the Code of Canon Law (\#607709) to include those groups formally designated by the terms "order" and "congregation." See http://www.vatican.va/archive/ENG1104/_P1Z.HTM (accessed June 25, 2016). Since the full title of the Sisters of Sion is "Congregation of Notre Dame de Sion" or "Congregation of Our Lady of Sion," the term "Congregation" will be used in this article.

${ }^{5}$ François Delpech, "Notre Dame de Sion et les juifs," in Sur les Juifs: Études d'histoire contemporaine (Lyon: Presses Universitaires de Lyon, 1983), 347. Theodore speaks of his being "reborn" (régénéré) in baptism as early as 1835. Theodore Ratisbonne, "Adéodat," in La philosophie du christianisme: correspondance religieuse de L. Bautain, vol. 2, ed. by Abbé Henri de Bonnechose (Paris: Dérivaux, 1835), xlvii. In doing so, Theodore uses a term that originates as early as the midfirst century (e.g., Rom 6:1-4). He also uses the term as it is deployed among nineteenth century French Jewish intellectuals to describe the process of transformation of Jews into members of mainstream French society; cf."Adéodat," liii. On the "le movement régénérateur" (movement of regeneration), see Jay R. Berkovitz, The Shaping of Jewish Identity in Nineteenth-Century France (Detroit MI: Wayne State University Press, 1989), 128-149.

${ }^{6}$ Delpech, "Notre-Dame de Sion et les juifs," 347-348. On the difference between conversionary efforts and proselytism, see a document issued jointly by the Pontifical Commission for Interreligious Dialogue, the World Council of Churches, and the World Evangelical Alliance, "Christian Witness in a Multi-Religious World; Recommendations for Conduct." (June 28, 2011), available on each of their websites, for example http://www.vatican.va/roman_curia/pontifical_councils/interelg/documents/rc_pc_interelg_doc_2011 1110_testimonianza-cristiana_en.html. 
Instead, Ratisbonne encouraged the sisters to focus on prayer for the conversion of the Jews, all the while being careful to respect their and others' consciences. ${ }^{7}$

Even before the Shoah, the Sisters began to move from their original supersessionist theology and desire for conversion of the Jewish people to dialogue, reciprocity and friendship. The factors that shaped the Sisters' journey from conversion to dialogue and enabled their contributions to Nostra Aetate include philosemitism, ressourcement, resistance to the Shoah and the Affaire Finaly (Finaly Affair). ${ }^{8}$ This article, then, will focus on the Congregation's evolution during the decades preceding and during the council in the context of these four elements. It will pay attention particularly to the sisters' work in France, where they had participated for decades in developing new ways of understanding, and will attend to the international context of the Congregation's development as reflected through various official documents.

\section{The Years of the Council (1959-1965)}

Angelo Giuseppe Roncalli was elected pope on October 28, 1958 and two months later, on January 25, 1959, announced his plan to convene an ecumenical council. On June 13, 1960, Jules Isaac made his historic visit to Pope John XXIII, asking for and receiving assurance that the pope would use the opportunity afforded by the council to raise his voice on the question of the "teaching of contempt." Pope John had already set something in motion before Jules Isaac's visit. On June 5, a few days before that meeting, he had created the Secretariat for Promoting Christian Unity. On June 6, he appointed Augustin Cardinal Bea as president and Bishop Johannes Willebrands as secretary. The pope asked Isaac to discuss his memorandum with Bea. On Sept. 18 pope and cardinal weighed Isaac's proposals and the decision was made to put this project under Bea, with the pope mandating "that the Secretariat for Promoting Christian Unity should also facilitate reflection on 'the Jewish question' during its preparation for the council." 9

\footnotetext{
${ }^{7}$ Theodore Ratisbonne, Trois Retraîtes à l'Usage des Religieuses (Paris: Librairie Poussielgue Frères, 1889), 85-91.

${ }^{8}$ While scholarship has taken account of the work of the Sisters of Sion in the development of Jewish-Christian dialogue, with the exception of two articles by Emma Green, reference to this group is missing in the English-language literature on Nostra Aetate itself. See her "Developing Dialogue: the Congregation of Our Lady of Sion and Nostra Aetate, 1945-1969," Ecumenical Trends 41 (February, 2012), 8-15 ; and "Sisters of Sion: the Nuns Who Opened Their Doors for Europe's Jews," The Atlantic.com, October 11, 2012, http://www.theatlantic.com/international/archive/2012/10/sisters-of-sionthe-nuns-who-opened-their-doors-for-europes-jews/263525/ (accessed Jan. 2, 2016).

9 Thomas Stransky, "The Genesis of Nostra Aetate," America, October 24, 2005, http://www.americamagazine.org/issue/547/article/genesis-nostra-aetate (accessed on April 26, 2015). Stransky continues, "The pope did not, as a myth was to say, directly mandate the drafting of a schema for the council itself." There had already been a number of documents from Protestant, Catholic and ecumenical/Interfaith groups, urging new relationships between Christians and Jews, beginning with "An Address to the Churches (the Ten Points of Seelisberg)" in 1947; for documents, cf. http://www.ccjr.us/dialogika-resources/documents-and-statements/roman-catholic/second-vaticancouncil/naprecursors (accessed September 23, 2015); John M. Oesterreicher, "Declaration on the Re-
} 
What role did the Sisters of Sion play in this unfolding narrative? Circles of collaboration had formed in the decades before World War II. Others, such as the Amitié Judéo-Chrétienne de France, developed after the war. These networks included some of the Sisters of Sion. ${ }^{10}$ Some of these women would participate in writing and editing material and in the extended conversation with scholars and Council Fathers that would result in the revolutionary document, Nostra Aetate. ${ }^{11}$

As has been well documented, the process of the emergence of Nostra Aetate was slow, lasting until the final months of the Council. Despite the intentions of Pope John XXIII and Cardinal Bea and his colleagues, the topic of the relationship of the Church to the Jewish people was removed from the agenda for the first session (1962) for theological and geopolitical reasons. ${ }^{12}$ Thanks to the immediate intervention of Cardinal Bea, the Pope asked that the matter nevertheless be moved forward. ${ }^{13}$

The Sisters of Sion's direct involvement with the Council text began the spring of 1963, before the beginning of the second session. The Congregation's general council ${ }^{14}$ foresaw further difficulties and decided that Sion's vocation required the Congregation's action. As Sr. Bénédicte Salmon recalls, the Congregation's general council believed it necessary that the Second Vatican Council should articulate in a document "a definition of the Jewish people which would situate the Jews in their proper place in a 'Christian' vision of salvation..." ${ }^{" 15}$ To achieve this, Sisters of Sion would need to work with bishops in the

lationship of the Church to Non-Christian Religions," in Commentary on the Documents of Vatican II, vol. 3, ed. Herbert Vorgrimler (Westminster: Herder and Herder, 1968), 8-17.

${ }^{10}$ E.g., Sr. Marie Pierre; see Olivier Rota, "Lettres de Jules Isaac à Soeur Marie Pierre de Sion à propos d' 'Israël et Nous'," Sens 282(2005): 98-103; Richard Francis Crane and Brenna Moore, "Cracks in the Theology of Contempt; the French Roots of Nostra Aetate," Studies in ChristianJewish Relations, 8 (2013): 1-28, http://ejournals.bc.edu/ojs/index.php/scjr/article/view/5265/4739 (accessed Sept. 29, 2015).

${ }^{11}$ Whether Nostra Aetate is "revolutionary" or "evolutionary" has been debated. John Oesterreicher, "Declaration...," 1 , notes :

... a Council, for the first time in history, acknowledges the search for the Absolute by other men [sic] and by whole races and peoples, and honours for the first time the truth and holiness in other religions as the work of the one living God. It is the first time also that the Church has publicly made her own the Pauline view of the mystery of Israel.

On the nature of Nostra Aetate as representing rupture, see Stephen Schloesser, "Against Forgetting: Memory, History, Vatican II," Theological Studies 67 (2006): 289-294. For a view of Nostra Aetate in the context of a hermeneutics of continuity, see Gavin D'Costa, Vatican II; Catholic Doctrines on Jews and Muslims (Oxford UK: Oxford University Press, 2014).

${ }^{12}$ Arab governments had been suspicious of Vatican intentions, believing that a proposed conciliar text signified favoritism on the part of the Vatican and collusion on the part of the State of Israel. See, for example, John W. O'Malley, What Happened at Vatican II (Cambridge MA: Harvard University Press, 2008), 220.

${ }^{13}$ O'Malley, What Happened, 220.

${ }^{14}$ A general council of a religious institute is a small group responsible for the central governance of the order. Councilors, with a superior general, are usually elected by the institute's general chapter.

${ }^{15}$ S. Marie-Bénédicte Salmon, Untitled paper, given Feb. 23, 1986, for the lay fraternity of Notre Dame de Sion, Paris; Archives-SIDIC/Paris. This document is unnumbered. In this article, numbers for archival material will be supplied when they are available. Sr. Marie-Bénédicte does not indicate either here or in her article of 2002, precisely what she means by the "proper place in a 'Christian' vision of salvation." See "La Congrégation Notre-Dame de Sion en France, pendant le Concile Vatican 
various countries where members of the Congregation were present. The French Sisters began immediately. On May 3, 1963, Sr. Bénédicte Salmon, sometimes accompanied by Sr. Magda Manipoud, began a series of visits with French bishops and theologians, most of whom were already known to the Sisters of Sion. These included Archbishop Jean-Marie Villot (Lyon), Bishop Joseph-Marie Martin (Rouen), Cardinal Pierre Veuillot (Paris), Fr. Yves Congar, O.P. (Strasbourg) and Fr. Henri de Lubac. ${ }^{16}$

On September 23, at Cardinal Veuillot's suggestion, Sr. Bénédicte went to Strasbourg to meet with Fr. Yves Congar. Congar listened carefully and then said:

It will be necessary to reintroduce a paragraph into the schema 'People of God' including what you say about the roots of the Church. Then it will be necessary to find a bishop to present it; it would carry rather a lot of weight if that were Cardinal Veuillot. Express the ideas that you have just presented in their logical sequence and then make a conclusion. Congar gave Sr. Bénédicte names of other bishops, and then gave her his own address in Rome so that they could stay in contact. ${ }^{17}$

Returning to Paris, Sr. Bénédicte enlisted the aid of Fr. Kurt Hruby, professor at the Institut Catholique in Paris, a theologian and scholar of Bible and Jewish studies. Hruby believed the team needed a Protestant voice, and enlisted Pastor Georges Richard-Molard. Hruby, Richard-Molard, and Sr. Bénédicte drafted four propositions:

1) Israel, the Jewish people, is situated within the unfolding of the history of the Church, of its mystery. This excludes the idea that this people is situated on a purely ethnic level and that the Jews are a people 'like others.' This removes the confusion between the State of Israel - two million Jews - whose existence poses difficult political problems, and the Jews -12 million people - about which the Church answers before God on a unique basis. 2) Israel, the Jewish people, is the "root people" of the Church (one had "forgotten" for centuries, Saint Paul's sentence: 'it is the root which bears you'), of the Christian mystery, of our history, of our sacramental system, of our morality. This does away with the idea of the 'substitution of the Church for Israel' and evokes the idea of 'fulfillment.' 3) Israel, the Jewish people, is the people who bear historic witness to the biblical revelation of the living God, of the fleshly reality of the Incarnation. It bears historic witness to the attitude of the human person confronted with the gift of God. This does away with the idea of a people preserved for the punishment of deicide. 4) Israel, the Jewish

II," Sens 271(2002): 475. Our discussion will suggest that this implied a recognition of Judaism according to Jews' self-understanding and the Church's essential rootedness in the Jewish people.

16 S. Marie-Bénédicte Salmon, Untitled paper, 12. Soeur Magda, Notre Dame de Sion (MarieMadeleine Manipoud) 1923-2005 (Lyon: privately published, 2006), 39.

${ }^{17}$ S. Marie-Bénédicte Salmon, "La Congrégation Notre-Dame de Sion en France pendant le Concile Vatican II," Sens 271 (2002): 477. 
people, has yet today, by unique right, a part linked to the Church in the unfolding of God's design in eschatology, according to the dialectic described by Paul in Romans 9-11. This does away with the idea of the Jewish people rejected by God." 18

The team sent this text to the French bishops and theologians Srs. Bénédicte and Magda had visited, as well as to Bishops Achille Liénart (Lille), François Marty (Reims), Émile Guéry (Cambrai) and Gabriel-Marie Garrone (Toulouse). They also sent the text to several theologians who were serving at the Council as periti: Yves Congar, Henri Denis, Henri Cazelles, Henri de Lubac. ${ }^{19}$ Between September 30 and October 18 the team received favorable responses from Rome, expressing commitment to working for passing the text. ${ }^{20}$ Pastor Richard-Molard had also contacted several Protestant theologians attending the Council (Hébert Roux, Oscar Culmann and Lukas Vischer), and they too gave the text a positive reception. ${ }^{21}$

The work accomplished by the sisters and their colleagues during this critical period was collaborative. It was constructed on the foundation laid by conversations, conferences, and publishing in previous decades by theologians such as Congar, Hruby, de Lubac, Cazelles, the circles around Paul Démann, Jules Isaac and others, including Sisters of Sion. These long-established relationships allowed for effective collaboration during this and other critical moments of the Council. ${ }^{22}$

On November 8, 1963, in the second session of the Council, Cardinal Bea brought a text to the floor, entitled "On the Attitude to Non-Christians, Especially toward the Jews," which was meant to form the fourth part of the schema on ecumenism. This somewhat resembles the text drafted by Sr. Bénédicte, Fr. Hruby and Pastor Richard-Molard, specifically in its affirming the patriarchal and prophetic roots of Christian faith, declaring that not all Jews, then or now, are responsible for the death of Jesus, and explicitly repudiating the deicide charge. ${ }^{23}$ It is not clear whether there is a direct relation between the two texts. What is certain is that a free-standing document emerged from this session, in response to a call primarily from delegates from Asia, Africa, and Latin America for the Council to treat Judaism alongside other non-Christian religions ${ }^{24}$

The next phase of the sisters' work was about to begin. In January of 1964, shortly after the close of the second session of the Council, the congregation moved its generalate from Paris to Rome, in order to facilitate collaboration with

\footnotetext{
${ }^{18}$ Salmon, "La Congrégation...," 477-478. For an analysis of the four points, see Paule Berger Marx, Les relations entre les juifs et les catholiques dans la France de l'après-guerre 1945-1965 (Paris: Éditions Parole et Silence, 2009), 459-460.

${ }^{19}$ Salmon, "La Congrégation," 478; cf. also, Salmon, Untitled paper, 10.

${ }^{20}$ Salmon, Untitled paper, 10.

${ }^{21}$ Salmon, Untitled paper, 10.

${ }^{22}$ Marx, Les relations, 456-462.

${ }^{23} \mathrm{http} / / / \mathrm{www} . c \mathrm{cjr}$.us/dialogika-resources/documents-and-statements/roman-catholic/second-vaticancouncil/na-drafts/1025-1963.

${ }^{24}$ O'Malley, What Happened, 221.
} 
the Vatican and the Council. The general chapter, held near Rome in Ariccia, January 1-22, 1964, elected Sr. Laurice as superior general of the Congregation of Our Lady of Sion. She would continue the congregation's engagement in these new developments, following the course established by her predecessor, Sr. Marie-Félix.

On January 15, a few weeks after he had presented to the Council a first draft of a text on the Jewish people, Sr. Marie-Félix invited Cardinal Bea to address the chapter delegates in order to assure those who might doubt the new directions being taken by the Congregation's leaders, that their "tournant apostolique" (apostolic or ministerial revolution, their turn from conversion of the Jews to dialogue) was indeed in line with new directions being taken by the broader Church. $^{25}$ Consequently, on March 21, 1964 Sr. Laurice wrote to the sisters in charge of the centers of study and to the Archconfraternity of Prayer for Israel (API, see below), asking for the suppression of all their printed material. Older publications, including prayer texts and material about the Congregation's work, were to be reviewed and either suppressed or rewritten. For those who had lived their lives praying for the Jews while hoping for their ultimate conversion, the request was wrenching. ${ }^{26}$

By mid-summer of 1964 the Council text on the Church and the Jewish people was in trouble once again. Serious theological differences between Cardinal Bea and Pope Paul VI over issues like deicide, as well as internal and external politics threatened to bury the document as "inopportune." $27 \mathrm{Sr}$. Laurice feared that the document would be lost. Consequently, on August 4, 1964, Sr. MarieDominique Gros, general councilor, wrote in her name, to the sisters working in the Congregation's centers for Jewish-Christian relations, asking them to ascertain which Council fathers would be most open to promoting approval of the document. $^{28}$ She advised the sisters to obtain letters of introduction. If necessary, they should act through priests in the bishops' confidence to arrange a conversation. Sr. Marie-Dominique underscored the need for discretion. The sisters would need to avoid polemic, including any reference to the Secretariat for Christian Unity since the Secretariat, including Bea himself, was unpopular with many in

\footnotetext{
${ }^{25}$ Augustin Cardinal Bea, "Aux religieuses de Notre Dame de Sion," unpublished conference, Rome, Italy, January 15, 1964; S. Marie-Dominique Gros, "La Congrégation Notre-Dame de Sion avant et après le concile Vatican II," Sens 271 (2002): 494-495. Cardinal Bea would reiterate his message in two further addresses: "Nouveau message de S. Em. Le Cardinal Béa aux Religieuses de N.D. de Sion," 13 novembre 1965 Rome, Archives Notre-Dame de Sion, Paris; "H.E. Cardinal Bea's talk to the Religious of Our Lady of Sion," 3 November 1966 Rome, Archives Notre-Dame de Sion, Paris. The texts of Cardinal Bea's conferences to the Sisters of Sion have not yet been numbered.

${ }^{26}$ Mary Boys, "The Sisters of Sion: From a Conversionist Stance to a Dialogical Way of Life," Journal of Ecumenical Studies 31 (1994): 38-40.

${ }^{27}$ Giovanni Miccoli, "Two Sensitive Issues: Religious Freedom and the Jews," in History of Vatican II; vol. 4, Church as Communion: Third Period and Intersession, September 1964-September 1965, ed. Giuseppe Alberigo and Joseph A. Komonchak (Maryknoll, NY: Orbis, 2003), 156.

${ }^{28}$ Lettre de S. M. Dominique aux provinciales et aux soeurs responsables du centres pour Israël, 4 août 1964, Série 3 G 6, "Secrétariat, communication à la congregation 1868-1975," Archives NotreDame de Sion, Paris. By 1964, these centers could be found in Paris, London, São Paulo, Montreal, Kansas City, Mo., and elsewhere.
} 
Rome, ${ }^{29}$ and there were marked differences between Paul VI and Bea. There should be no mention of the word "deicide" since Paul VI opposed use of the term. ${ }^{30}$ Rather, sisters should present a brief note, well based in Scripture, not focused on anti-Semitism, but on the question of the Jews' responsibility in the condemnation of Jesus - which would allow the bishop to ask that the Council produce a declaration with a clear statement on the non-responsibility of Jews of today in the death of Jesus. Following this instruction, the sisters made contacts, both in person and through correspondence. ${ }^{31}$ Srs. Magda and Marie-Dominique, both members of the general council, became close collaborators with Fr. Bruno Hussar and others in writing draft material for what would become Nostra Aetate \#4. ${ }^{32}$ Nostra Aetate was finally approved on October 28, 1965 thanks to the collaboration of many such as the Sisters of Sion.

The role played by the Sisters of Our Lady of Sion in the story of Nostra Aetate did not end with the approval of the document. A few days after the document's promulgation in November 1965, a group of Council Fathers led by Bishop Léon-Arthur Elchinger of Strasbourg and several theologians engaged in the production of Nostra Aetate met to consider ways to implement the new document. At the initiative of Fr. Bruno Hussar, three sisters from Sion's general council (Srs. Edward, Magda and Marie-Dominique) were invited to the gathering. The Sisters of Sion were asked to take charge of the project. Sr. Edward accepted the responsibility under the direction of Fr. Cornelius Rijk, founding SIDIC (Service Internationale de Documentation Judéo-Chrétienne/International Service for Jewish-Christian Documentation), first in the new Generalate and then in 1970 in a large apartment on the Piazza Venezia. ${ }^{33}$

How did a community of women who prayed daily for the conversion of the Jews evolve into a group that included a highly trained cadre who contributed to the writing of Nostra Aetate? The transformation was complex, beginning long before the Second Vatican Council and proceeding without a straight trajectory. In what follows, we will discuss that transformation through the lens of certain

\footnotetext{
${ }^{29}$ See Miccoli's discussion of the conflict in the crisis of October, 1964; "Two Sensitive Issues," 166193.

${ }^{30}$ O'Malley, What Happened, 222; Oesterreicher, "Declaration," pp. 112-114.

${ }^{31}$ See the correspondence between Mother Maura Clune, provincial superior of the Sisters of Sion in the United Kingdom and Ireland and John Carmel Cardinal Heenan, September 21 and September 23, 1964, Archives of Sion Centre for Dialogue and Encounter, London. Gregory Baum, one the scholars who would join John Oesterreicher in October of 1964 in the drafting of Nostra Aetate, was in contact with Sisters Louis Gabriel (Charlotte Klein) and Theodora (Mary Kelly) at the London Centre. Green, "The Sisters of Sion"

${ }^{32}$ Soeur Magda, 42-43.

${ }^{33}$ In 1969, the Centre d'étude et d'information pour Israël (Center for Study and Information for Israel) in Paris was renamed "SIDIC-Paris." Both SIDIC and SIDIC-Paris were staffed by Sisters of Sion, and others, both cleric and lay. However, they operated independently of each other. On Oct. 17, 2002, the library and documentation service of SIDIC were transferred to the Gregorian University, where both remain, in conjunction with the University's Institute for the Study of Religion and Culture and the Cardinal Bea Center for Jewish Studies. SIDIC-Paris was dissolved on January 30, 2016, and ceded place to the newly founded CIRDIC (Centre Chrétien d'Initiatives pour les Relations et le Dialogue entre Juifs et Chrétiens. CIRDIC is under independent direction, although it maintains cordial relations with the Sisters of Sion.
} 
official documents and in the context of four significant contributing factors: philosemitism, ressourcement, resistance to the Shoah, and the Affaire Finaly (Finaly Affair).

\section{Philosemitism}

Philosemitism (literally, "love of the Jews"), was a spiritual, theological, and socio-political perspective that Olivier Rota argues originated towards the end of the nineteenth century in France, partly in response to the Dreyfus Affair. ${ }^{34}$ The underlying theological question, for philosemitism as for its inverse antiSemitism, was how to understand continued Jewish existence in the face of the coming of Christ and Jewish "refusal" to recognize him as Messiah. ${ }^{35}$ From a socio-political perspective, its basis was a concern for the boundaries, whether ecclesiastical, or socio-political being threatened by modernity. Many consequently turned to an "obsessive preoccupation with ordering," into which Jews, the "epitome of incongruity," did not fit. ${ }^{36}$

Philosemitic responses, in contrast to the better-known anti-Semitic ones, reflected an assumption that Jews could be assimilated if they converted. Jews thus should cease to be Jews, preserving no Jewish particularity or distinction. ${ }^{37}$ In this, philosemitism shared supersessionist aspects of classic Christian antiJudaism, al-though it did not teach racial anti-Semitism or discrimination, and some philosemites explicitly eschewed the charge of deicide. ${ }^{38}$

Rota's locating the first emergence of philosemitism at the end of the nineteenth century, with its first premises emerging in the 1870's, acknowledges its antecedents in the work of Theodore Ratisbonne, the founder of Notre Dame de Sion, and his brother Marie-Alphonse whose conversion experience was profoundly influential in his brother's life and ministry. ${ }^{39}$ Theodore Ratisbonne's relationship to Judaism was complicated. ${ }^{40}$ Even prior to his conversion in 1827 at the age of twenty-five, his writing bore evidence of the theological antiJudaism of his era. Initially, his conversion brought him into conflict with his

\footnotetext{
${ }^{34}$ Essai, 149. While Zucotti would place the origin of this shift in thinking after World War I, the founding of the API in 1905 and the life and work of Aimé Pallière suggest a much earlier point of origin; Susan Zuccotti, Under His Very Windows: the Vatican and the Holocaust in Italy (New Haven: Yale University Press, 2000), 61; Catherine Poujol, Aimé Pallière (1868-1949); un chrétien dans le judaïsme (Paris: Desclée de Brouwer, 2003).

${ }^{35}$ Rota, Essai, 35-64.

${ }^{36}$ Zygmunt Bauman, "Allosemitism: Premodern, Modern, Postmodern," in Modernity, Culture and "The Jew," ed. Bryan Cheyette and Laura Marcus (Stanford CA: Stanford University Press, 1998), 153.

${ }^{37}$ Bauman, 153 .

${ }^{38}$ E.g., the Amici de Israele; cf. Jean Levie, "Decret de suppression de l'Association des 'Amis d'Israel', " Nouvelle Revue Théologique 55(1928): 536; M.R. Macina, "Amis d'Isräl; une initiative premature mais instructive," Sens 228 (1998): 243.

${ }^{39}$ Rota, Essai, 79-81.

${ }^{40}$ Julie Kalman, Rethinking Antisemitism in Nineteenth-Century France (Cambridge UK: Cambridge University Press, 2010), 58-60. For an early account of his life, including the events surrounding his conversion, see "Adéodat," xxxiii-lxii.
} 
family; Alphonse, his youngest brother, would remain estranged from Theodore until his own conversion in 1842. Yet despite his "apostasy," Theodore was not disowned by his family. Indeed, as a seminarian nearing ordination, he was present at his father's deathbed in $1830 .{ }^{41} \mathrm{He}$ maintained close ties with many family members; ${ }^{42}$ the long estrangement from Alphonse appears to have been an exception. $^{43}$

Theodore and Alphonse Ratisbonne were but two examples of the French Jewish elite who converted to Roman Catholicism during the early and midnineteenth century. ${ }^{44}$ These "apostates" varied in their relationships with their birth families and communities, though all assumed, to one degree or another, traditional theological anti-Judaism. They were caught in the complexities of an historical period in which both anti-Judaism and philosemitism served as inverted elements of a discourse through which French people, Catholic and secular, liberal and integrist, could think about and speak about what it meant to be French in the modern world. ${ }^{45}$

In the period between World War I and World II, participants in philsemitic circles made organized efforts to convert Jews. Our Lady of Sion had initiated a new project, the "Association of Prayer for Israel" (API), conceived in 1903, ultimately founded in 1905, to seek Jews' conversion through gatherings for prayer, gatherings for lectures and conversation, and, where possible, a monthly dedicated Mass, preferably in a group. With the Sisters and Fathers of Sion, members

\footnotetext{
${ }^{41}$ Kalman, Rethinking Antisemitism, 60. See Theodore's account, Mes Souvenirs (Rome: Congrégation de Notre-Dame de Sion, n.d.; originally published in 1884), 154-155. But see the much more complicated version in the account of 1835, "Adéodat," in Philosophie du Christianisme, vol. 1, pp. lx-lxi.

${ }^{42}$ This is particularly evident in his correspondence, as illustrated in his letters with his brothers Henri and Adolphe, and his niece Helena Ratisbonne; Memoirs; Supplement; Texts and Documents (Rome: privately published, n.d.), 7-18.

${ }^{43}$ The complexity of relationships in the Ratisbonne and similar families leads Thomas Kselman to note that "apostasy" and "conversion" are not neutral terms. He suggests that "interweaving" is a better word in these contexts; "Turbulent Souls in Modern France: Jewish Conversion and the Terquem Affair," Historical Reflections/Réflexions Historiques 32(2006): 104; cited in Kalman, Rethinking Antisemitism, 60.

${ }^{44}$ Kalman, Rethinking Antisemitism, 46-70; Thomas Kselman, "The Bautain Circle and CatholicJewish Relations in Modern France," The Catholic Historical Review, 92 (2006): 177-196; Jonathan I. Helfand, "Passports and Piety: Apostasy in Nineteenth-Century France," Jewish History 3(1988): 5983; Philippe-E. Landau, "Les conversions dans l'élite juive strasbourgeoise sous la Restauration," Archives Juives 40(2007): 131-139. These people included several strasbourgeois besides Theodore and - eventually -- Alphonse, as Landau notes. Others included Lévy Gumpel (Ignace Xavier-Morel), David Drach, Simon Deutz, Jacob Liberman, Joseph and Augustin Lémann. While some of these had extensive Jewish educations, others were ill-equipped to face the questions of meaning in a Jewish community and a broader French society undergoing social upheaval and redefinition; cf Jay Berkovitz, The Shaping of Jewish Identity in Nineteenth-century France (Detroit: Wayne State University Press, 1989), 114-116.

${ }^{45}$ Rota, Essai, 15-18 and passim. On anti-Semitism and philosemitism as discourse, see Altfelix, "The 'Post-Holocaust Jew'," 41-56; Bauman, "Allosemitism," 143-156; Samuel Moyn, "Antisemitism, Philosemitism and the Rise of Holocaust Memory," Patterns of Prejudice 43 (2009): 1-16.
} 
recited daily the prayer "God of All Goodness." ${ }^{, 6}$ As in other works of the Congregation, conversion of the Jews was a subject of prayer, but proselytism was forbidden. Its main centers were in Jerusalem at the Convent of the Ecce Homo and in Paris at the Motherhouse of the Sisters of Sion, but it quickly spread globally, beyond the boundaries of the congregation, with widespread ecclesiastical approval. ${ }^{47}$ The sisters played a central role in the activities of the API; their convents became an international network of centers, often containing libraries and serving as meeting places.

The API's official publication was Annales de la Mission de N.-D. de Sion en Terre Sainte, frequently abbreviated as Annales de Terre Sainte. Like much of the literature emerging from philosemitic circles, its articles frequently expressed substitution theology's traditional claim that the Church was the New Israel. Nonetheless, the discovery of the Jewishness of Jesus, Mary, and the first Christians, and continued reflection on Romans $9-11$ by groups such as the API suggested the possibility of another road, an alternative to antisemitism. This perspective was "anchored in a narrative of continuity between biblical Judaism and Christianity," ${ }^{48}$ where conversion from Judaism to Christianity was understood as a more benign continuation, a passage from an "incomplete" Judaism to its completion in belief in Jesus as the Christ. For example, in 1907, Fr. Fages, the archdeacon of Notre Dame wrote in the journal:

Let us not forget that the Jewish nation, which was in the past such a great and mighty race ... is the one who, in order to sustain what it thought to be the truth, buried itself under the ruins of the Temple. Let us not forget that we are, we Christians, the children of this race, for we have been parented into Christianity by the Jews. Let us remember Saint Paul's word: 'it is the root that bears the branches. ${ }^{49}$

In 1925, Fr. Théomir Devaux was elected superior general of the Fathers of Notre Dame de Sion. He recounts that he had scarcely moved in to 68 rue NotreDame des Champs when he received a group of visitors who challenged him on the subject of the "specific apostolate for Israel." The group included Stanislas

\footnotetext{
${ }^{46}$ The text of the prayer reads: "God of goodness, Father of mercies, we beseech you through the immaculate heart of Mary, and through the intercession of the patriarchs and holy apostles, to turn a look of compassion on the remnant of Israel, so that they may come to the knowledge of our only Savior Jesus Christ, and share in the precious graces of the Redemption. 'Father, forgive them, for they know not what they do';" Directoire des religieuses de la Congrégation de Notre-Dame de Sion, $4^{\text {th }}$ ed. (Paris: Maison-Mère, 1925), 46.

${ }^{47}$ Olivier Rota, "L'Association de Prières pour Israël (1903-1966); une association révélatrice des orientations orthodoxes de l'Église face aux Juifs," Bulletin de Centre de recherche français à Jérusalem 13 (2003): 6-21.

${ }^{48}$ Rota, Essai, 122.

${ }^{49}$ M. l'abbé Fages, on the occasion of the installation of M. l'abbé Cazais as pastor of the church of St. Laurent, January 1906, cited in "Assocation de prières en faveur d'Israël," Annales de la Mission de N.-D. de Sion en Terre Sainte 115 (1907), p. 12. http://gallica.bnf.fr/ark:/12148/bpt6k5788908s/f15.image.r=Fages; accessed June 26, 2016; cited by Rota in "L'Association de Prières pour Israël," 10.
} 
Fumet, René Schwob, Oscar de Férenzy, Joseph Bonsirven, Francesca Van Leer and Fr. Anton Van Asseldonk and Jacques Maritain, who wanted to develop a Christian response to the "Jewish Question" that would counter the kind of antiSemitism present in many Christian circles. Maritain's suggestions included special meetings and study circles. Such activities were already under way, but needed coordination and development, and they were looking to Sion for leadership. ${ }^{50}$ The Fathers of Sion served in this manner most visibly through the 1920's and ' 30 's. The rule of cloister limited the activities of the sisters outside institutional contexts. Nonetheless, they were involved in the collaboration through meetings, writing and editorial work.

In 1928, Fr. Devaux established the periodical La Question d'Israël which sought to forge links between Christians and Jews. The periodical's offerings suggest two objectives. The first was directed to Christians, and sought to combat anti-Semitism through education regarding the Jewish background of Jesus and the New Testament, as well as contemporary Judaism. It also proposed "perspectives on Judaism, speaking about relationships of Judaism to Catholicism, and explaining Jewish bitterness as a consequence of centuries of persecution." It combatted racism and anti-Semitism as being "contrary to the Christian spirit and destroying the hope of conversion." ${ }^{, 51}$ Secondly, the periodical was directed to the Jews, presenting various aspects of Catholic teaching in the hopes of attracting them to convert. ${ }^{52}$ This dual work continued to develop through the 1930's in the face of escalating anti-Semitism. For some, like the Fathers of Sion, the increasingly hostile context caused the struggle against anti-Semitism to take precedence over desire for conversions. ${ }^{53}$ Joseph Bonsirven, a Jesuit scholar of New Testament and Rabbinic Judaism, and the Fathers of Sion were major contributors to the pages of the periodical. It also advertised and reported on various relevant activities like the lecture of the Catholic thinker Aimé Pallière, especially at the synagogue in the Rue Copernic ${ }^{54}$ or gatherings at the rue Froidevaux.

These gatherings point to an important element in the development of philosemitism: the role of friendships. As early as the 1920's Jews and Christians were coming together to discuss topics of interest, even when members of one group wished to convert members of the other. Henri De Lubac cited the words of Jules Monchanin, another participant, in describing his experience of people gathering

\footnotetext{
${ }^{50}$ Rota, Essai, 108.

${ }^{51}$ Rota, Essai, 116-117.

${ }^{52}$ Rota, Essai, 117.

${ }^{53}$ Catherine Poujol, Les Enfants caches; L'affaire des enfants Finaly (1945-1953) (Paris: Berg International, 2006), 160-161.

${ }^{54}$ Madeleine Comte, Sauvetages et baptêmes; Les religieuses de Notre-Dame de Sion face a la persecution des Juifs en France (1940-1944) (Paris: L'Harmattan, 2001), 48-49. Pallière, a Catholic, took as his guide and mentor, Elias Benamozegh, who encouraged him not to convert to Judaism, but to remain a Christian under the rubric of the Noahide law. Pallière was opposed to any attempt to convert Jews. Rather, his attention was focused on reform within liberal Judaism, as well as exposing Christians to the riches of Jewish tradition. See Marx, Les relations, 115-117; Catherine Poujol, Aimé Pallière (1868-1949); Un chrétien dans le judaïsme (Paris: Desclée de Brouwer, 2003), 96-98, 289293.
} 
in the home of Elizabeth Belensson on the rue Froidevaux, calling it "a little oasis of peace in the midst of hatred." ${ }^{55}$ In these gatherings, Jews (Chouraqui, Fleg) and Christians (Massignon, Monchanin, Devaux, Pallière, Maritain, Fessard), and converts from Judaism to Christianity (Belensson, Glasberg, de Menasce) all met regularly to read a psalm in Hebrew and in French, and listen to a paper, often an exegesis led by a Jew and a Christian. ${ }^{56}$ People gathered, as well, at the home of Jacques and Raïssa Maritain at Meudon, ${ }^{57}$ at the Fathers of Sion, or elsewhere to hear presentations and engage in conversation. Participation was fluid, with people becoming friends and attending meetings and conferences in the different venues. ${ }^{58}$

La Question d'Israël was closed down after the Occupation of Paris in 1940. After the end of the Second World War, Cahiers Sioniens, under the direction of the Fathers of Sion, took its place. The journal was placed under the charge of Fr. Paul Démann in 1947, and he was joined in 1953 by another Father of Sion, Geza Vermes, and a lay doctoral candidate, Renée Bloch. The work published in $\mathrm{Ca}$ hiers Sioniens would further help transform Catholic perspectives on Jews and Judaism. ${ }^{59}$

Although Christian thinkers engaged in philosemitic conversations differed one from another, they shared a widespread desire for the conversion of the Jews. For all the intellectual and social courage in crossing religious, cultural and intellectual borders in order to meet one another, there remained a profound ambivalence in these circles, including the Fathers and Sisters of Sion. Others sometimes displayed tendencies both to essentialism and ahistoricism that could occlude the experience of Jews as persons, despite their close friendships with Jews. ${ }^{60}$ For all of convert Raiissa Maritain's self-understanding as a Jew within the Church, and despite Jewish converts to Catholicism struggling to articulate an identity that was both Catholic and Jewish, she and her colleagues seemed unaware that conversion of the Jewish people ultimately would mean the erasure of "Jewish distinctiveness."

\footnotetext{
${ }^{55}$ Henri de Lubac, Résistance chrétienne à l'antisémitisme; Souvenirs 1940-1944 (Paris: Fayard, 1988), 16-17; Poujol, Aimé Pallière, 307-309; Poujol, "Oscar de Férenzy ou les limites du philosémitisme dans l'entre-deux-guerres," Archives juives 40 (2007): 18-19.

${ }^{56}$ Françoise Jacquin, "L'abbé Monchanin, précurseur du dialogue judéo-chrétien 1935-1938," Revue d'histoire de l'Église de France 80 (1994): 90-91; Poujol, Aimée Pallière, 307.

${ }^{57}$ Brenna Moore, "Philosemitism under a Darkening Sky: Judaism in the French Catholic Revival (1900-45)," Catholic Historical Review 99 (2013): 277-281.

${ }^{58}$ Brenna Moore develops the theme of friendship in intellectual circles during the period of the French Catholic revival in "Friendship and the Cultivation of Religious Sensibilities," Journal of the American Academy of Religion 83 (2015): 437-463.

${ }^{59}$ Marx, Les relations, 164-171.

${ }^{60}$ Moore, "Philosemitism under a Darkening Sky," 267-276; Richard Francis Crane, "Heart-Rending Ambivalence'; Jacques Maritain and the Complexity of Postwar Catholic Antisemitism," Studies in Christian-Jewish Relations 6 (2011): 3-4, http://ejournals.bc.edu/ojs/index.php/scjr/article/view/1820 (accessed November 30, 2015).

${ }^{61}$ Adam Sutcliffe and Jonathan Karp, "Introduction: a Brief History of Philosemitism," in Philosemitism in History (Cambridge UK: Cambridge University Press, 2011), 3. Moore and Crane discuss the thought of writers Léon Bloy and Charles Péguy, as well as philosopher Jacques Maritain.
} 
The API would end in 1966. The Congregation's shift in institutional commitment would no longer allow even for a well-intended supersessionism joined to a certain "philosemitism." But the API and similar groups had played an important role in the development of a context that would eventually produce Nostra Aetate. Above all, friendships were formed through prayer and religious exploration, personal and theological. Mixed with a theology of conversion and supersessionism, a passion grew for the study of the Bible and Jewish sources, colored by an undertone of continuity and respect that suggested the possibility of an alternative relationship to that of scorn, hatred and even violence. The continued re-reading of Romans 9-11 would extend into the post-World War II period. It would be foundational to the new ecclesiology developed by Maritain, Journet, Démann, Bonsirven, De Lubac and the Jesuits of Lyon and to the Sisters' development as well. ${ }^{62}$

The men and women of Sion were part of the ferment of French philosemitism in all its ambivalence and possibility. ${ }^{63}$ Théomir Devaux played a major role not only as the superior general of the Fathers of Sion from 1925 to 1937 , but also through his later work at 68 rue Notre Dame des Champs, the rescue work of the war years, and then post-War developments. The women, usually limited to activities within their own insitutions (convents, schools and other places of ministry), served as colleagues and partners in leading the A.P.I. , through meetings, writing and publication, and then the work of rescue. The intellectual work, the personal relationships and networks developed during these years would be foundational to their pre-Conciliar growth and then to the creation of Nostra Aetate.

\section{Ressourcement $^{64}$}

In 1946, the first post-War general chapter of the Sisters of Sion convened in Paris. Despite what might be thought of as more practical needs, the report of the chapter's proceedings called for the Sisters to be educated in Bible, the Church Fathers, the sources of the Congregation's own tradition, as well as in Jewish studies - including contemporary issues - and theology. ${ }^{65}$ This reflected not only the leadership's desires for the sisters' ongoing education, but also the broader intellectual and theological context in which the delegates had assembled, ressourcement. This second element shaping the evolution of the Sisters of Sion's thinking was a new way of understanding Christian, specifically Roman Catholic,

\footnotetext{
${ }^{62}$ Thérèse-Martine Andrevon, "Le mystère d'Israël dans l'oeuvre de Jacques Maritain," Recherches de Science Religieuse 101 (2013): 211-231; Rota, "Le second concile Vatican,” 304.

${ }^{63}$ Comte, Sauvetages et baptêmes, 27-50.

${ }^{64}$ The term "ressourcement" was "coined by the poet and social critic Charles Péguy (1873-1914); Gabriel Flynn, "The Twentieth-Century Renaissance in Catholic Theology," in Ressourcement: a Movement for Renewal in Twentieth-Century Theology, eds. Gabriel Flynn and Paul D. Murray (Oxford: University Press Scholarship Online, 2012), 3.

${ }^{65}$ Compte-rendu du XIVe Chapître, Paris, 12-23 août 1946, section "Israël - Pensionnats," Série 1 G 14, general chapter of 1946, Archives Notre-Dame de Sion, Paris. Rota, "Une double fidélité," 70. "Israël" designates "the Jewish people," and will continue to do so in theological writing through the Second Vatican Council period.
} 
tradition that had fully emerged in the 1920's and 1930's in response "to the challenges of the time, most notably the intensification of secularization." ${ }^{, 66}$ Its exponents, as reflected in the sisters' report, literally sought to return to the sources ${ }^{67}$ not to legitimate Church structures, ${ }^{68}$ but rather to mine the past to renew a vision of the Church in relation to the contemporary world. It was a process on behalf of the whole Church and included a large number of laity, women and men alike. It joined the ongoing turn to history and to Jewish sources for understanding Jesus that had already emerged in the pioneering work of Christian scholars like the Jesuit Joseph Bonsirven (1880-1958), and that had shaped the promotion of friendship between contemporary Christians and Jews discussed above. ${ }^{69}$ The circles engaged in philosemitism and ressourcement were permeable in the period between the two World Wars, with the same figures and salons pursuing both methodologies and ideologies. ${ }^{70}$ While many of those associated with ressourcement were men, ordained members of religious orders, its nonhierarchical and non-clerical quality was one of its striking features. ${ }^{71}$ These laity, the "théologiens en veston" (theologians in lounge suits or lay clothes, as distinct from clergy wearing soutane or collar) ${ }^{72}$ included writers and teachers, historians and philosophers, even some scientists. The professional theologians of this movement taught and wrote in service to the broader community, in conversation with these broader groups and in response to lay needs. ${ }^{73}$

Some ressourcement thinkers also engaged in ecumenical, interfaith and interreligious dialogue. Raïssa and Jacques Maritain's guests in their Meudon salon included not only fellow Catholic philosophers, but Russian Jews including Marc and Bella Chagall and other assimilated Jewish émigrés. Similarly diverse groups gathered at the rue Froidevaux and rue Notre-Dame des Champs, where de Lubac

${ }^{66}$ Paul D. Murray, "Explanding Catholicity through Ecumenicity in the Work of Yves Congar: Ressourcement, Receptive Ecumenism and Catholic Reform," International Journal of Systematic Theology, 13(2011):

http://web.a.ebscohost.com.ezproxy.cul.columbia.edu/ehost/pdfviewer/pdfviewer?sid=7809bf124c12-43d8-949a-b34b09a783da\%40sessionmgr4009\&vid=3\&hid=4104 (accessed Oct. 20, 2016).

${ }^{67}$ See Katherine Davies and Toby Garfitt, eds., God's Mirror; Renewal and Engagement in French Catholic Intellectual Culture in the Mid-Twentieth Century (New York: Fordham University Press, 2015); Jürgen Mettepenningen, Nouvelle Théologie -New Theology: Inheritor of Modernism, Precursor of Vatican II (London: T \& T Clark, 2010). The 1942 Jesuit establishment of the series "Sources chrétiennes" was part of the ressourcement project.

${ }^{68}$ De Lubac and others were clear that such a legitimation was the self-appropriated mission of "Roman" theologians; Fouilloux, "Nouvelle théologie' et théologie nouvelle (1930-1960)" in L'histoire religieuse en France et en Espagne: Colloque international, casa de Velázquez, 2-5 avril 2001: actes, ed. Benoît Pellistrandi (Madrid: Casa de Valázquez, 2004): 413-417.

${ }^{69}$ Laurence Deffayet, "Le Père Joseph Bonsirven: un parcours fait d'ombres et de lumières," Archives Juives 40 (2007): 30-44. The controversial nature of the pioneers' work was illustrated in the Biblical Commission's forbidding the defense of Bonsirven's thesis in 1910, the height of the Modernist crisis.

70 Thomas Stransky, "Forum Essay," 759.

${ }^{71}$ This was also true of the broader French Catholic revival that evolved into what would come to be called - both positively and negatively - the "new theology" ("la nouvelle théologie" or "la théologie nouvelle"); cf. Étienne Fouilloux, "Nouvelle théologie,"” 413-415.

${ }^{72}$ Fouilloux, 419.

${ }^{73}$ Fouilloux, 419. 
often went for conversation, as we observed earlier. The method of procedure at rue Froidevaux was inspired by the Lyon priest, Jules Monchanin, who inaugurated, the practice of praying a psalm and then listening to a presentation.

Monchanin, a close friend of De Lubac, was convinced of the universality of salvation. His friends included men and women from all communities and walks of life. He was most attracted to Jews, however, whose numbers in France continued to increase through the 1930's as anti-Semitism in central Europe continued to grow. Horrified, he wrote, "We must not sleep during Israel's agony." ${ }^{, 74}$ Monchanin's experience showed him the possibility of close friendships between people of different religious traditions. Moreover, he believed deeply in the ongoing significance of the existence of a post-biblical Judaism, even and especially, in the face of the Nazi threat. The lectures Monchanin gave in 19351938 until he left for India were attended by Massignon, Pallière, Jacques Maritain, Chouraqui and others.

Louis Massignon also appears among the ressourcement thinkers. Soldier, diplomat, scholar and teacher of Islam, he too was a border transgressor, whose own spiritual life was nourished by the classics of Islamic mysticism. While not unproblematic, his understanding of Judaism, Islam and Christianity as "Abrahamic religions" would be a significant influence on the development of Nostra Aetate. ${ }^{75}$ The presence of people like Massignon and Monchanin in the circles in Lyon and Paris indicates just how broad was the vision of the Church, inspired by the thinking generated by personal contact with people and texts of different traditions, as well as by the emerging ecclesiology of theologians like de Lubac, Chenu and Congar. The latter would work with the Sisters through the 1950's and during the Council years, including their intervention in the work on Nostra Aetate. These theologians' thinking would eventually open the way, at the Second Vatican Council, for a new understanding of the Church's relationship to the Jewish people. The theological breadth of the conversations in groups such as these had a direct influence on the development of the thinking of the Sisters of Sion.

Women played roles in the ressourcement. Elizabeth Belensson opened her home on the rue Froidevaux and convened a salon. Some women collaborated as scholars. Raïssa Maritain is the best known, at the heart of the circle of friends and acquaintances gathered in her home at Meudon. Their presence in the project of ressourcement signified a broadening of gender roles in this period, when "Roman" theology was the province of ordained men. ${ }^{76}$ These "spaces" for women in the enterprise of ressourcement created added context for the work of the Sisters of Sion before, during and after World War II. ${ }^{77}$

\footnotetext{
${ }^{74}$ Jacquin, “L’abbé Monchanin,” 86.

${ }^{75}$ Anthony O'Mahony, "Louis Massignon: a Catholic Encounter with Islam and the Middle East," in God's Mirror; Renewal and Engagement in French Catholic Intellectual Culture in the MidTwentieth Century, eds. Katherine Davies and Toby Garfitt (New York, NY: Fordham University Press, 2015), 230-251.

${ }^{76}$ Brenna Moore, "Into the Catacombs of the Past" "Women and Wartime Trauma in the French Catholic Ressourcement Project (1939-45)," in God's Mirror, 186-209.

${ }^{77}$ The Freiburg Circle, established in 1948 by Gertrud Lückner and Karl Thieme, is a primary example of the presence of women in German-speaking theological contexts focused on developing a new
} 


\section{Resistance to the Shoah}

The experience of the Shoah was a third element in the development of a new way of thinking among Christians, including Sisters of Sion. The Nazi invasion of France lent a new meaning to the significance of loving Jewish people. The Vichy government handed over the Jews to the Nazis, but many courageous French citizens - regardless of religious affiliation - formed networks engaged in resistance efforts. Many of those participating in philosemitic circles and the emerging ressourcement also endangered their own lives for the sake of rescue and resistance. ${ }^{78}$ Henri de Lubac, who had been engaged in pre-War philosemitic and ressourcement circles, was involved in rescue efforts based in Lyon, where he worked with Germaine Ribière and some of the Sisters of Sion as part of a network of underground communities of Jewish and Christian solidarity called Amitié chrétienne (Christian friendship). De Lubac supervised the editing of $\mathrm{Ca}$ hiers du Témoignage chrétien (Notebooks of Christian Witness).Those involved in the production of Témoignage Chrétien sought to demonstrate the incompatibility of Christianity and Nazism, and to inform readers of the unfolding horror, reporting details as they emerged. ${ }^{79}$ The Sisters of Sion took an active role in stockpiling and distributing the periodical.

It is not surprising that people engaged in pre-War philosemitic and/or ressourcement circles should now commit themselves to rescue and resistance. Philosemitic groups included Jews or converts from Judaism who were vulnerable to the forces of the Nazi occupation. Moreover, deep friendships had been established over the decades preceding the Occupation. Thus, rescue and resistance not only were political commitments, but also were driven by personal identity and relationships. Ressourcement circles were committed to "essentially a practical theology engaged in an open, critical, and sometimes militant fashion with the most pressing issues affecting contemporary society." Some suffered imprisonment or execution for their courage. ${ }^{80}$

Sion participated in rescue efforts. Depending on the particular location, this meant providing false documents (identity papers, ration cards, birth certificates, etc.), hiding places, and/or channels of communication for rescue and other Re-

understanding of the relationship of Judaism and Christianity; the importance of the Freiburger Rundbrief as the premiere German-language journal on the topic perdures; Michael Phayer, From Enemy to Brother, 190-192; Elias Füllenbach, "Shock, Renewal, Crisis: Catholic Reflections on the Shoah," in Antisemitism, Christian Ambivalence and the Holocaust, ed. Kevin Spicer (Bloomington IN: Indiana University Press, 2007), 202-234.

${ }^{78}$ Richard Francis Crane and Brenna Moore, "Cracks in the Theology of Contempt: the French Roots of Nostra Aetate," Studies in Christian-Jewish Relations 8(2013): 20 http://ejournals.bc.edu/ojs/index.php/scjr/article/view/5265 (accessed Jan. 2, 2016).

${ }^{79}$ Henri de Lubac, Résistance chrétienne à l'antisémitisme (Paris: Fayard, 1988), 143-158; At the Service of the Church; Henri de Lubac Reflects on the Circumstances That Occasioned His Writings, trans. Anne Elizabeth Englung (San Francisco: Ignatius Press/Communio Books, 1993), 50-55; Phayer, The Catholic Church and the Holocaust, 128;

${ }^{80}$ Flynn, "Twentieth-Century Renaissance," 12, 14. 
sistance workers. ${ }^{81}$ After the Nazis shut down his journal Question d'Israël, and confiscated the library of the Fathers of Sion in 1940, Fr. Devaux with a group of Sisters of Sion and others hid Jews. Their Paris-based network was responsible for saving hundreds by procuring false papers and by hiding children, both in boarding schools like those directed by Notre-Dame de Sion, and with sympathetic families in the countryside. The boarding school, under Mother Francia, hid girls among its student body. The convent of Notre Dame de Sion in Grandbourg, a peaceful place in a Paris suburb, became a refuge for exhausted adults as well as a school. Part of another network, the small convent of Sion in Lyon served as a residence for women university students. Although it could not hide many people, these included several Jewish women, and the sisters were part of a wider rescue network. The sisters' community and school in Grenoble, close to the Swiss border, collaborated in rescue efforts as did the communities of Marseille, Biarritz, Le Mans, Saint Omer, and Gérardmer. ${ }^{82}$

\section{Post-War Developments: General Chapters and l'Affaire Finaly}

The documents of the general chapters of the years 1946-1964, as well as certain other official letters and reports, suggest that the congregation's evolution from conversion to dialogue was slow, and that the ambivalence that was so much a part of philosemitism and often ressourcement would fade slowly. At the same time, both philosemitism and ressourcement had given the Sisters of Sion tools for their own transformation: a focus on Romans 9-11, the experience of friendships with Jews, the exposure to biblical, Jewish and theological studies that were indeed the "return to the sources." And behind all of this intellectual and spiritual richness loomed the experience of the Shoah, and its bitter reality in the lives of many of the sisters.

The relationships forged through the sisters' work during the war served as a basis for post-War transformation as well. The journey from "loving the Jews" to witnessing genocide and risking their lives to hide people brought many of the sisters to a new level of understanding their vocation. The impact of the Shoah had been personal, part of the daily lives of many, if not most of the sisters living in France and Nazi-occupied Europe. The true "face" of anti-Semitism was bru-

\footnotetext{
${ }^{81}$ Compte, Sauvetages et baptêmes, 111, 117-118.

${ }^{82}$ Communities in Antwerp and Rome were also involved in rescue work. The sisters in London received children from the Kindertransport. The convent in Rome also offered a hiding place to more than one hundred and eighty-seven Jews beginning in October, 1943; Susan Zuccotti, "Response to William Doino Jr. and the Film Lo Vuole il Papa," Contemporary Church History Quarterly 21 (2015), 4, https://contemporarychurchhistory.org/2015/09/response-to-william-doino-jr-and-the-filmlo-vuole-il-papa-2/ (accessed September 30, 2015); Zucotti, Under His Very Windows; the Vatican and the Holocaust in Italy (New Haven: Yale University Press, 2000), 189-193, 194; Zuccotti recounts interviews with two Sisters (Virginia and Emilia Badetti), who stated that provisions were delivered regularly from the Vatican; also Michael Phayer, The Catholic Church and the Holocaust, 1930-1965 (Bloomington, IN: Indiana University Press, 2000), 124, 126-131. Fr. Devaux and seven of the sisters have been named "Righteous Gentiles," though many more men and women of Sion were involved in the work; http://www.notredamedesion.org/en/page.php?id=82\&T=9 (accessed Oct. 1, 2015).
} 
tally apparent; beyond the work of rescuing and hiding Jews, several sisters, friends and students were deported. One sister, Sr. Gila, was executed. ${ }^{83}$ In the words of Sr. Marie-Dominique, "we would discover that, while we were asking God to forgive the Jews their infidelity, they were dying in the extermination camps, victims precisely of their fidelity." ${ }^{84}$

Directly after the cataclysm of the Shoah, Mother Marie-Amédée, the superior general, called the General Chapter of $1946{ }^{85}$ The introduction to the chapter report references the "terrible upheavals of these past years (terrible secousses de ces dernières années)." to attend, either because of problems with visas or the expense of the journey. Yet, in spite of these less than ideal circumstances, those gathered sought a chapter of reform. The chapter report reflects a systematic analysis of the life and work of the Congregation, and recommends adaptation for the future.

The report states forthrightly that all houses of Notre-Dame de Sion are to collaborate in the "fundamental work" of the Congregation, which is the work concerning the Jewish people. It recommends that the young sisters be provided theological training according to individual capabilities and responsibilities. ${ }^{87}$ In addition, young sisters may dedicate part of their vacation time to study circles on Scripture, the texts on the origins of Sion, contemporary Judaism or other topics that will help them to "deepen their sense of their special vocation (se pénétrer de leur vocation spéciale)." this reference to the study of Scripture, a practice that was not usually considered essential for pre-Vatican II Roman Catholics. ${ }^{89}$ This focus on Scripture would contribute to the transformation of the Congregation's self-understanding in the coming decades.

This chapter confirms the place of the Ancelles and their mandate to work especially in poor Jewish milieux. The Ancelles, originally the "Ancelles of Our Lady, Queen of Palestine," were a small group of Sisters of Sion who dressed in lay clothes when outside their homes. They had been an independent community

\footnotetext{
${ }^{83}$ Catherine Poujol, L'Eglise de France et les enfants juifs; des missions vaticanes à l'affaire Finaly (1944-1953) (Paris: Presses universitaires de France, 2013), 296.

${ }^{84}$ S. Marie-Dominique Gros, "La congrégation Notre-Dame de Sion avant et après le concile Vatican II," 489.

${ }^{85}$ A general chapter is a meeting of elected and ex officio delegates from the entire Congregation. It is held regularly, and its function is to review the life and ministry of the Congregation, with particular attention to the fulfillment of the previous chapter's mandate. It then sets new directions for the Congregation. A full study would also include documents like journal entries or personal letters. However, general chapter documents suggest trends emerging from the Congregation and point to new directions. On the chapter of 1946 and the chapters held successively and their significance, see Olivier Rota, "Une double fidélite," 67-77.

${ }^{86}$ Compte-rendu du XIVe Chapître de la Congrégation 12 Août-23 Août 1946, Série 1 G 14, General chapter of 1946, Archives de Notre-Dame de Sion, Paris.

${ }^{87}$ Compte-rendu du XIVe Chapître general de la Congrégation 12 Août-23 Août 1946, section "Scolasticat."

${ }^{88}$ Compte-rendu du XIVe Chapître general, section “Oeuvres, Israël-Pensionnats,” p. 5, 20.

${ }^{89}$ Only in 1949 were novices authorized to have a complete Bible; previously they had only the Psalms and chosen texts. Cf. Comte, "De la conversion à la rencontre," 110.
} 
in British mandate Palestine that joined the larger Congregation of Our Lady of Sion in $1936 .{ }^{90}$ As Sisters of Sion they continued their ministry of "direct apostolate" to the Jewish communities where they lived, first in pre-War Palestine, and then in Europe. The Ancelles lived either alone or in small groups in Jewish neighborhoods such as the Marais in Paris, especially among the poor. Like the teaching sisters, the contemplatives, and the Fathers of Sion, the Ancelles were never to proselytize coercively. ${ }^{91}$

The general chapter of 1946 urged the Ancelles to enter into contact with Jewish intellectual circles, organizing study circles and conferences in order to transmit "Christian ideas" (les idées chrétiennes)." 92 The Chapter also confirmed the Ancelles' special responsibility for the Archconfraternity of Prayer for Israel. They were to train members, especially among priests. The most committed of the these members could become associated with the API's ministry and serve as "Agrégées de Sion," in keeping with the desire of Theodore Ratisbonne who had founded this lay group in $1855 .^{93}$

The chapter made decisions regarding work with Jewish converts, cautioning the sisters not to set goals for certain numbers of baptisms. Rather, they were to develop religious sensibilities among Jews, make known Christian ideas and thus prepare the way for conversion. Catechumens were to undergo instruction for a year and, in so far as possible, be given a godmother who would continue to support them after baptism. In every house there was to be a sister who would be in touch with the center of the work assigned to the Ancelles. Finally, in so far as possible, teaching sisters were to interest their students in "the work."

A missionary perspective clearly informs these decisions. The chapter, however, maintained the same concern for respect of conscience found in earlier documents. Jewish and Protestant students in Sion schools, in general, were not required to attend either prayer or religious education classes. The chapter document envisioned special books for Jewish children in Sion's schools, teaching "sacred history" and including prayers drawn from the psalms and other biblical texts.

The report's section on Sion's work for Israel ends with a request that the sisters be careful when speaking, even among themselves about Jews. They are to exercise caution lest they offend someone by an insensitive word. The recommendation suggests that the leadership of the Congregation realized that, for all

\footnotetext{
${ }^{90}$ Lettre de Mère Marie Amédée à la congregation, 10 juillet 1936, Série G3, Circulars from the Superior General 1931-1975, Archives Notre-Dame de Sion, Paris. The Ancelles' mandate of "direct apostolate" was confirmed by the general chapter of 1946; cf. Compte-Rendu du XIVe Chapître général de la Congrégation 12 août - 23 août 1946, section "Oeuvres, Israël - Pensionnats," p. 20-21.

${ }^{91}$ Marx, Les relations, 65-71; Comte, Sauvetages et baptêmes, 22-23. During the Shoah, the Ancelles were disproportionately present among the rescuers.

${ }^{92}$ Compte-Rendu du XIVe Chapître general, section "Observance des Constitutions," \#50, p. 5.

${ }^{93}$ Compte-Rendu du XIVe Chapître general, section "Oeuvres. Israël - Pensionnats," p. 21.

${ }^{94}$ Compte-Rendu du XIVe Chapître general, section "Oeuvres. Israël - Pensionnats," p. 21. In preVatican II Sion documents "the work" refers to the Congregation's presence to the Jewish people, whether indirectly through prayer or more directly through, lectures, courses, or instruction of converts.
} 
Sion's institutional dedication to the Jewish people, some of the sisters lacked sensitivity and were even anti-Semitic. In other words, even with the limitations embedded within these new standards, their universal application would have significant challenges.

The Sisters and Fathers of Sion were working in a broader context in which ecumenical and interfaith understanding were developing in significant ways. The newly founded International Council of Christians and Jews held its first conference at Seelisburg the next year, 1947. Its document ${ }^{95}$ would help to lay the groundwork for Nostra Aetate. Paul Démann, a Father of Sion attended, and there he met Jules Isaac, a history teacher from Aix-en-Provence who had lost his wife and daughter to the concentration camps. ${ }^{96}$ Isaac had spent the war in hiding, writing all the while. That meeting launched a close personal and professional friendship. With Edmond Fleg, Jules Isaac would found, on February 26, 1948, the Amitié Judéo Chrétienne. ${ }^{97}$ In 1960 Isaac's visit would prompt John XXIII to promise to "do something" to place the "Jewish question" on the agenda of Vatican II, soon to begin. Relationships between the sisters, Jules Isaac and Edmond Fleg developed and helped to shape the sisters' emerging perspectives. ${ }^{98}$

The Fathers of Sion remained important figures in the development of a changing discourse about the relations between Christians and Jews. Paul Démann took over the direction of Cahiers Sioniens in 1948 and until its closing in 1955, it was one of the premier journals in its field, publishing the works of the leaders of mid-twentieth century French theological scholarship, Jews and Christians, lay people as well as members of men's religious orders and even some hierarchs. ${ }^{99}$ Beginning in October of 1951 and continuing until October of 1962, the Fathers of Sion, also published the Échos de Notre-Dame de Sion, Bulletin de l'A.P.I. under the leadership of Fr. Devaux. This periodical, aimed at a broader audience than the scholarly Cahiers Sioniens, published reports of sermons, lectures and summaries of articles on a wide range of topics: history, sociology, liturgy, theology and Scripture. ${ }^{100}$

While Cahiers Sioniens and Échos de Notre Dame de Sion were under the direction of the Fathers of Sion, sisters were involved. Moreover, the sisters were engaged in other editorial venues. The Ancelles published the Bulletin des Ancelles in 1947 and 1948 as a means of linking members living individually or in small groups in poor Jewish neighborhoods such as the Marais (Paris). They shared their knowledge of the social structures of a Jewish community with sisters engaged in other milieux. Reports of their activities suggest a clear understanding of their work as grounded in the links between Jews and Christians

\footnotetext{
95 "An Address to the Churches (the Ten Points of Seelisburg," http://www.ccjr.us/dialogikaresources/documents-and-statements/ecumenical-christian/567-seelisberg.

${ }^{96}$ M.-R. Macina, "Le role de Paul Démann à Seelisberg," Sens no. 5(1999): 434-439.

${ }^{97}$ Marx, Les relations, 135.

${ }^{98}$ Olivier Rota, "Lettres de Jules Isaac à Soeur Marie Pierre de Sion à propos d'Israël et Nous," Sens (2005): 98-103; Marx, Les relations entre les juifs et les catholiques, 70.

${ }_{99}$ S. Marie-Dominique Gros, n.d.s., "La congregation Notre-Dame de Sion avant et après le concile Vatican II," 490.

${ }^{100}$ Marx, Les relations, 52-53.
} 
found in the Bible. ${ }^{101}$ Their approach would influence the sisters engaged in education.

In collaboration with others, including the Fathers of Sion, the sisters began an in-house publication, Israël et Nous (November, 1950-October, 1965), as a means of linking their far-flung communities. Contents included reports on various apostolic involvements (teaching, religious education, etc.), and articles meant to provide an ongoing education for the sisters. Themes included "Advent and Israel," the great figures of the Hebrew Bible in the liturgy, and Jewish feasts. Israël et Nous sometimes reprinted articles from Cahiers Sioniens, making scholarly articles directly accessible to the sisters. Israël et Nous was, of course, subject to the limitations of the mid-century theology of substitution. Nonetheless, it placed at the sisters' disposal a resource of current thinking and thus would move forward the development of their thinking in the years before Vatican II. ${ }^{102}$

The General Chapter of 1951 formalized some of the decisions and recommendations made in 1946, developing several important themes. At the same time, ambivalence remained in the sisters' thinking about the relationship between Christians and Jews. The report bespoke a keen awareness of the world "outside." The introduction of Part 1, "Esprit de la Congrégation et observance des Constitutions" (Spirit of the Congregation and Observance of the Constitutions) acknowledged the newness of the post-War situation, with its "breathtaking...transformation of social structures." ${ }^{, 103}$ Part 2 names the threat of communism. ${ }^{104}$ Echoing a call from Pope Pius XII the chapter report urgently calls for response, stating that the Congregation's continued existence in this changing world depends on its adapting. ${ }^{105}$

The 1951 document echoes the renewal characterizing ressourcement: "People today speak a lot about a return to the biblical sources and it is there that we find what integrates our spirituality, both evangelical and biblical." ${ }^{106}$ It urges su-

\footnotetext{
${ }^{101}$ Marx, Les relations, 65-69; Comte, Sauvetages et baptêmes, 22-23.

${ }^{102}$ Paule Berger Marx, "'Israël et Nous'. La revue des Soeurs de Notre-Dame de Sion de Paris, de 1950 à 1965," Sens no. 2 (2005): 78-97. See Jules Isaac's letters to Sr. Marie-Pierre about the journal in Rota, "Lettres de Jules Isaac," 96-103.

${ }^{103}$ Compte-rendu Chapître Général XVe, 31 juillet-10 août 1951, Première Partie, "Esprit de la Congrégation et observance des Constitutions," Série 1 G 16, General Chapter of 1951, Archives de Notre-Dame de Sion, Paris.

${ }^{104}$ This had a particularly vivid significance for the Sisters of Notre-Dame de Sion, who had sisters in Romania, Hungary and Bulgaria. Latin and Greek rite Catholics were subjected to fierce persecution in Romania, and sisters were given the choice to disband their communities or to move into internment camps with members of other religious congregations. See the documentary Interrupted Lives; Catholic Sisters under European Communism, written and produced by Sr. Judith Ann Zielinski, osf with Sr. Margaret Nacke, csj and Sr. Mary Savoie, csj as executive producers. http://interruptedlives.org/.

${ }^{105}$ Première Partie, "Esprit de la Congrégation et observance des Constitutions;" Annus Sacer to the First Congress of the States of Perfection, Dec. 8, 1950; AAS 40 (1951), 26-36. http://www.vatican.va/archive/aas/documents/AAS-43-1951-ocr.pdf (accessed Dec. 11, 2015).

106 "On parle beaucoup aujourd'hui de retour aux sources bibliques et c'est là partie intégrante de notre spiritualité, éminement évangélique et biblique." Compte-rendu Chapître Général XVe, 31 juil-
} 
periors to arrange biblical or theological lectures for the sisters, and asks sisters to deepen their knowledge of the texts, with a focus on the Gospels, Epistles and Acts of the Apostles, ${ }^{107}$ directing them to study Bible more intensively during vacation times if that is not possible during the school year. The section dedicated to "Israel" notes that for sisters effectively to introduce people to the "magnificence of the Bible," they must themselves know the sacred texts. They should focus on the literal text, in keeping with Pope Pius XII's September 30, 1943 encyclical Divino Afflante Spirito. ${ }^{108}$

The Chapter reiterates that the principal mission of the Congregation is the sanctification of its members and "Israel." This "mission" has three "aspects." The first eloquently echoes prior philosemitic understandings, speaking of:

...the grandeur of Israel, the people of the Bible and of the Messiah, whose place in the plan of redemption is absolutely unique, that the Church prolongs like the stalk prolongs the root and which, mysteriously separated from her in the present, will one day be reintegrated, according to St. Paul's prophetic word. ${ }^{109}$

The second aspect is reparation: making amends for Jewish refusal to accept Jesus as Messiah and the perceived Jewish responsibility for the death of Jesus. The report links reparation to the "providential gift of the Lithostrotos," the firstcentury paving stones beneath the Congregation's Convent of the Ecce Homo in Jerusalem. In 1951, many people, including some scholars, believed that this was the place where Jesus was held prisoner and scourged by the Romans, and then taken before Pontius Pilate. ${ }^{110}$ Citing Rom 11:28, the 1951 delegates clarify that the expression "accursed people" (peuple maudit) is "inexact" for God has not cursed his people. Furthermore, the word "deicide" needs to be properly understood. 2 Pet 3:17 demonstrates that the charge of deicide is not materially true since those responsible did not know what they were doing. In addition, the 1566

let-10 août 1951, Première Partie “Congrégation et observance des Constitutions," Série 1 G 16, General Chapter of 1951, Archives de Notre-Dame de Sion, Paris.

107 The document does not mention study of the Hebrew Bible.

${ }^{108}$ At http://w2.vatican.va/content/pius-xii/it/encyclicals/documents/hf_p-xii_enc 30091943 divinoafflante-spiritu.html (accessed December 13, 2015). The chapter document mistakenly cites the encyclical as "Spiritu afflante."

${ }^{109}$ Compte-rendu Chapître Général XVe, Deuxième Partie, "Israël."

${ }^{110}$ Rev. Mother Marie Godeleine, superior of the Ecce Homo Convent, worked closely with Fr. Hugues Vincent of the École Biblique in Jerusalem, overseeing the excavations of 1931-1933 and 19341937. Traditional belief identified the Praetorium as being in the Fortress Antonia. The French Dominican P. Hugues Vincent laid out the case for this position in his article "Le Lithostrotos évangélique," Revue biblique 49 (1952): 513-530. In the same issue, P. Pierre Benoît challenged Vincent's position, placing the Pretorium in Herod's palace, rather than the Fortress Antonia. In 1955, Sr. Marie Aline Battut defended her doctoral dissertation at the Sorbonne, supporting Vincent's position; cf. La Forteresse Antonia à Jerusalem et la question du Prétoire (Jérusalem: Franciscalium, 1956). Following the 1966 excavations, Father Pierre Benoît again challenged a first-century date for the Lithostrotos, and placed it in the Hadrianic era. See Benoît's summary of earlier debates in 'L'Antonia d'Hérode le Grand et le Forum Oriental D'Aelia Capitolina," Harvard Theogical Review, 64 (1971): 135-167. 
Catechism of the Council of Trent teaches the responsibility of every person for the death of Jesus. ${ }^{111}$ Thus, delegates emphasize, reparation is primarily in relation to ourselves, Christians making amends for all sin, including our own, as having a role in the death of Jesus.

However, the text continues, underlining what the writers consider to be the gravity of Israel's "betrayal." The report states that since the death of Jesus, Jews have wandered through the world as a separated people. Thus, the "mystery of Israel" is double: "on the one hand, grandeur and sanctity; on the other, lowliness and sin." The reflection on reparation ends saying that "God has given to Sion [the gift of the Lithostrotos], as an incessant call to reparation for Israel's refusal in the rejection of its Messiah." This echoes certain tendencies in pre-war and then-current philosemitic thinking. The motif of reparation took on a particularly compelling note in view of the "gift" of the Lithostrotos and is stated in a way that could all too easily reinscribe traditional anti-Judaism.

The third aspect of Sion's mission is "the apostolate of Israel." "We are all, as religious of Sion, missionaries sent by the Church not exclusively, but first of all, to Israel." While external ministries vary, all are to offer their lives for the salvation of Israel, whether as contemplatives, educators or Ancelles. The Ancelles "go directly to Israel." They are not, however, to limit themselves solely to service in the Jewish community, but rather to bring Christ's message to the various "paganized" environments in which they find themselves. ${ }^{112}$ They are to attempt to form Christian communities where Jews, whether converts or not, can feel welcome.

The educators, who comprised the majority of sisters engaged in external ministry, had no less a mandate to work for the Jewish people. Their first task is to combat anti-Semitism among the children and all those with whom they have contact. Consistent with philosemitic goals, the report presents this as a way of preparing for the "return of Israel." and provides clear procedures through Bible study and prayer. ${ }^{113}$ Teaching sisters will also be assigned to instruct catechumens and are to let local bishops know that they are available to work with Jewish adults. While only a few will undertake this task, all are called to the apostolate of welcome and hospitality to all, Jews and non-Jews alike, extending material assistance when necessary. ${ }^{114}$

Chapter delegates recognized the particular difficulty facing the educators, especially in the context of their personal spirituality, of integrating the demands of teaching with the concern for the Jewish people. Delegates suggested two possible solutions. The first was offering one's day "for Israel" and the other was continual immersion in Scripture. Mother Marie Edward was charged by the Chapter to undertake supervision of further study of these questions. ${ }^{115}$

\footnotetext{
${ }^{111}$ See http://www.ccjr.us/dialogika-resources/primary-texts-from-the-history-of-the-relationship/275$\underline{\text { trent. }}$

${ }^{112}$ Compte-rendu Chapître Général XVe, Deuxième Partie, "Israël."

${ }^{113}$ Compte-rendu Chapître Général XVe, Deuxième Partie, "Israël."

${ }^{114}$ Compte-rendu Chapître Général XVe, Deuxième Partie, "Israël."

${ }^{115}$ Compte-rendu Chapître Général XVe, Deuxième Partie, "Israël."
} 
The report contains two cautionary paragraphs regarding combatting antiSemitism. The first responds to the charge on the part of some that the Sisters of Sion focused too exclusively on their work with and for the Jewish people. Chapter delegates reminded the sisters that they are mandated from the beginning of the Congregation's history, to have a particular care for "Israel" and to extend themselves to all. ${ }^{116}$ The Jewish people thus have a privileged place not only for the Congregation, but in relation to Christ the Redeemer and to the Church.

The second caution warns sisters to be careful about the way they speak about Jews. They should never cause people to say, "The Sisters of Sion were founded for the Jews and they are themselves anti-Semites." 117 This echoes the 1946 general chapter report's cautionary note. Its repetition suggests a complicated environment even within the sisters' communities, indicating that, for all the labor of rescue, the presence of Jewish students, parents and others, the issue of anti-Semitism among the sisters is still sufficiently marked to warrant note at the general chapter.

The chapter of August 1951 elected Mother Marie-Félix as superior general. On November 2, 1951, she wrote her first circular letter to all the superiors of the Congregation. It is a wide-ranging summary of her perspective on the life of the Congregation. She references the August chapter, with its cautionary note against exclusivity. Sisters are to present the Congregation's vocation as universal, directed first to the Jewish people, but to "all countries, races, religions, and conditions." Mother Marie-Félix encourages the superiors, "Let us show to those outside [the Congregation] that we work rather for a rapprochement between Jews and Christians than for premature conversions. A reputation for 'proselytism' would damage our ministry more than serve it."118 Her wording is noteworthy. Mother Marie-Félix urges a path of relationship, possibly reflecting the influence of Paul Démann whose language and ideas she echoes. ${ }^{119}$ However, she is still ambivalent, clearly discouraging proselytism or "premature" baptisms, but not criticizing the tradition of praying for the conversion of the Jews; nor does she question the sisters' working with Jews seeking baptism. She says nothing about the "Prayers for Israel," recited by all the sisters and absolutely nothing about the desire for the eventual conversion of the Jewish people. Finally, while the 1946 and 1951 chapter documents only suggested anti-Semitism among some of the Sisters, Mother Marie-Félix's first circular includes a specific reference to a "lack of charity" in some communities towards sisters of Jewish origin. ${ }^{120}$ Consistent with the ambivalence of the general chapter that elected her, Mother Marie-Félix

\footnotetext{
116 This finds inspiration in Theodore Ratisbonne's posthumously published Trois Retraites, 88-89.

${ }^{117}$ Chapître Général XVe, Deuxième Partie, "Israël."

${ }^{118}$ Lettre circulaire de Mère Marie-Félix addresséee aux Révérendes Mères Supérieures, 2 novembre 1951, p. 11, 3 G 3, "Secréteriat, communication à la congrégation 1868-1975," Archives de NotreDame de Sion, Paris.

119 Olivier Rota, "Dépasser les cadres du philosémitisme. La vision oecuménique de Paul Démann," Archives Juives 40 (2007): 124; Rota, Essai, 239-240

${ }^{120}$ Lettre de Mère Marie-Félix, 2 novembre 1951, p. 12.
} 
continues the pre-War current of philosemitism found among the Fathers and Sisters of Sion as well as in the broader circles in which they participated.

\section{L'affaire Finaly}

The energetic development emanating especially from the Sisters and Fathers of Sion in Paris and Lyon, as well as dozens of colleagues, lay, clerical and religious, underwent what one person called an "electro-shock" in 1953 with the bursting open of L'Affaire Finaly (the Finaly Affair). ${ }^{121}$ This provided a fourth and definitive element in transforming Sion's understanding of Jews and Judaism. At the center of the scandal were two little boys, Robert and Gérald Finaly, born in 1941 and 1942 in Grenoble to Hungarian Jewish refugees from the Nazis. Fritz and Annie Finaly had the boys circumcised at birth; they clearly intended them to be raised as Jews. They gave them to the Sisters of Sion in Grenoble for safeguarding in 1944; the boys were placed with Mlle. Antoinette Brun, directress of the city's day-care center. Fritz and Annie Finaly died in Auschwitz, but in February 1945, relatives appeared to retrieve the children. Mlle Brun refused to surrender the boys and had them baptized in 1948. A court case ensued and eventually, on January 8, 1953, the Grenoble court of appeals ordered Brun to hand over the children. Brun refused again. This time she asked the Sisters of Sion superior in Grenoble, Mother Marie-Antonine, to help her hide the children. With Mother Marie-Antonine's assistance, the boys were taken on January 30, 1953 by her sister Denise Jannot Bleuze to the Catholic College Saint Louis-de Gonzague in Bayonne on the French side of the Spanish border. ${ }^{122}$ On February 2, Robert and Gérald Finaly were then taken over the Pyrenees into the Basque country of Spain. They remained there until the end of June when Germaine Ribière found them and returned them to France to be reunited with their family. ${ }^{123}$

On February 3, Mother Marie-Antonine informed Mother Marie-Félix, the superior general of the congregation, what was transpiring. ${ }^{124}$ The following day, Mother Marie-Antonine was arrested and jailed. Mother Marie-Dominique, superior of the Sion convent in Marseille, who was also involved, was charged on March 3 by the prosecutor of Grenoble and was also imprisoned until March $10 .{ }^{125}$

Brun had not told the Sisters of Sion that family members had appeared in 1945. Moreover, her baptizing the children without permission of at least one

\footnotetext{
${ }^{121}$ Madeleine Comte, "De la conversion à la rencontre," 110.

${ }^{122}$ Poujol, L'Église de France et les enfants juifs, 341.

${ }^{123}$ Jacob Kaplan, L'affaire Finaly (Paris: Éditions de Cerf, 1993), 16-20; Germaine Ribière, L'affaire Finaly; ce que j'ai vécu (Paris: Centre de Documentation Juive Contemporaine, 1998).

124 Poujol, Les Enfants caches, 179.

${ }^{125}$ Poujol, Les Enfants Cachés, 175; Poujol, L'Église de France et les enfants juifs, 252-253. Poujol notes that ten members of men's religious orders were arrested in February and March of 1953 in connection with the kidnapping of Robert and Gerald Finaly; L'Église de France, 340. Prior to the simplification of practices mandated in the general chapters of 1964 and 1969-70, "Mother" was title given to Sisters of Our Lady of Sion who had made final vows. "Reverend Mother" or - more simply - "Mother" were titles given to superiors.
} 
parent or - in their absence - a guardian, was against traditional Church policy. ${ }^{126}$ However, Church policy also required that those baptized be raised Catholic. It is important to note that Mother Marie- Antonine acted without any communication with the superior general, Mother Marie- Félix; rather, she acted in accord with Cardinal Gerlier of Lyon, whom she had consulted, and in obedience to the Holy Office in Rome. ${ }^{127}$

Mother Marie-Félix made every effort as soon as she was informed of the kidnapping to find the children. ${ }^{128}$ However, she and her council did not distance themselves from Mother Antonine and Mother Marie-Dominique. Rather, the Sion administration stood behind them, not defending their actions but not condemning them either. The sense of betrayal on the part of the Jewish community was compounded not only by the recent trauma of the Shoah, but also by the history of Christians baptizing and kidnapping Jewish children. ${ }^{129}$ But, Mother Marie-Dominique later acknowledged that the Affaire and subsequent public disgrace, the sanction it gave to anti-Semitism and anticlericalism, and the mistrust and feeling of betrayal among Jews it caused led many in the Congregation, including its leaders, to reflect, learn, and undergo their own "conversion." Mother Lucie, then a general councilor, said, "With the Finaly Affair, it seemed to us more and more clear that our task is not conversion, but rapprochement between Jews and Christians in mutual respect." "We do not know the Jews," said Mother Marie-Félix in the wake of the Affair. Many years later, Mother MarieDominique interpreted her words:

Indeed, in our reactions to the course of the Affaire, many of us had not taken into serious consideration the feelings of the family of the two Finaly children; we had not been sensitive enough to the strength of the family ties, especially in a family which had lost several of its members in the Shoah. ${ }^{130}$

For a century, Notre-Dame de Sion had been deeply connected to the Jewish community, through study circles and lectures, publications, relationships with Jewish children and parents in the schools, instruction of converts, and social

\footnotetext{
${ }^{126}$ Gros, "La Congrégation," 490-491; Marx, Les relations, 238-245.

${ }^{127}$ Gros, 490; Compte, "De la conversion à la rencontre," 111.

${ }^{128}$ Poujol, Les Enfants Cachés, 180.

${ }^{129}$ Perhaps the most well-known example is the case of Edgardo Mortara. See David I. Kertzer, The Kidnapping of Edgardo Mortara (New York, N.Y.: Alfred A. Knopf, 1997); Marx, Les relations, 234.

${ }^{130}$ Gros, "La Congrégation," 491. The impact of the Finaly Affair continues to reverberate. See A1berto Melloni, "Pio XII al nunzio Roncalli: non restitute I bimbi ebrei," Corriere della Sera (Dec. 28, 2004), cited by Catherine Poujol, recounting the history of a document found in the Centre national des archives de l'Eglise de France at Issy-les-Moulineaux in a dossier entitled "Nonciature - enfants cachés." containing communication from the nuncio, Angelo Roncalli, to Cardinal Pierre-Marie Gerlier (Lyon) dated April 30, 1947 which instructs the cardinal not to return children who had been baptized while in hiding. The document was published without Poujol's permission, and the ensuing controversy led her to undertake further research. In that effort, she says that Notre-Dame de Sion and the French church opened their archives in order to cast light on the situation. See L'église de France et les enfants juifs, 1-2.
} 
work among the poor. Jews were part of Sion's life. Yet, in 1953, the superior general, considering the ramifications of the Finaly Affair, had to admit that "we do not know the Jews." There is immense sadness in these words, for the full impact, not only of anti-Semitism, but the profound ambivalence of philosemitism had been made manifest in a series of events that swept up, not only the Sisters of Sion, but a whole cast of people - including Antoinette Brun and Mother MarieAntonine - who had risked their lives to save Jews only a few years previously.

\section{After l'Affaire Finaly}

The leaders of the Sisters of Sion, however, were not paralyzed either by the scandal of l'Affaire Finaly or by their own remorse and shame. A gradual transformation that the French sisters came to call "le tournant apostolique" (the apostolic revolution) followed. The Congregation's general administration organized a conference for July 10-16, 1955, inviting delegates from all geographical regions of the Congregation, with the theme "An Information Session on Various Aspects of the Mystery of Israel" (Session d'information sur divers aspects du Mystère d'Israël). The program was filled with names of scholars who had been engaged in the topic for many years, including two Sisters of Sion. ${ }^{131}$

Theological change is seldom straightforward or consistent. Mother MarieFélix's concluding directives were mixed in their tone. She included a long discussion of how the sisters' call to welcome Christ functions as a kind of reparation for Jewish resistance to welcoming him, but she accompanied these remarks with profound comments on the search for God and openness to the Other. ${ }^{132}$ In the same address, Mother Marie-Félix announced the establishment of a permanent committee at the level of the general administration that would continue the session's discussions, outlining a research agenda to be undertaken in all the houses. ${ }^{133}$ This committee would also prepare the next conference and help the Superior General reorient the whole Congregation. In spite of this, Mother Marie-Félix concluded, asking whether it would be possible to create near the Sion houses community groups who would welcome people into Christian life. Former students might help to form such groupings. ${ }^{134}$ The 1955 conference marked a breakthrough, but the philosemitic interest in the conversion of the Jews remained.

This closing statement is interesting for what it says and for what it does not say. The first half of the document expresses a profoundly contemplative spirituality and continues the theme of reparation that characterized earlier elements in the Congregation's spirituality, as well as some philosemitic thinking. ${ }^{135}$ Mother

\footnotetext{
${ }^{131}$ Marx, Les relations, 309-310.

${ }^{132}$ Mère Marie-Félix, Session sur Israël-Séance de Clôture - 17 Juillet 1955 - Directives de Notre Mère Générale, p. 3, 3 G 3, Circular letters from the superior general 1931-1975, Archives de NotreDame de Sion, Paris.

${ }^{133}$ Mère Marie-Félix, Session sur Israël 1955, p. 4.

${ }^{134}$ Mère Marie-Félix, Session sur Israël 1955, p. 5.

${ }^{135}$ Session sur Israël, 2.
} 
Marie-Félix still referred to work with converts. At the same time, she made clear that the conference had set something in process that would engage the whole Congregation.

In October 1955, the Motherhouse opened a study center for research and encounter (Centre d'étude et d'information pour Israël) in Paris under the direction of the general council and Mother Colette, succeeded by Mother MarieEdward. ${ }^{136}$ Similar centers opened across the globe (e.g., London, Montreal, San Jose, São Paulo, Brussels). ${ }^{137}$ In 1957, a house was established in Paris for young sisters from around the Congregation to study Hebrew and Jewish studies. Sisters trained there were to disseminate new ideas and ways of thinking to the whole congregation. ${ }^{138}$

Documents from the general chapter of 1957 show a marked shift from earlier theologies. There is a serious attempt to rethink the theme of reparation. This motif was still very important in the thinking as well as the spirituality of many in the Congregation, leadership and members alike. In its discussion of the theological foundations of its mission to Israel, the report reflects on Theodore Ratisbonne's teaching that, modelling themselves on Mary at the foot of the cross, Christians are called to imitate Christ and participate in acts of reparation. The sisters are to imitate her, to unite themselves to her: "Mary's fidelity is, from the Incarnation, the perfect model of our vocation of reparation." 139

This section of the report clearly states that Sion's mission has a dual orientation: to the Christian people and to the Jewish people. Delegates found biblical grounding in Paul's letter to the Romans, noting that Israel is the olive tree and Christians the grafted branches. Continuing the use of Romans 9-11 from pre-war philosemitic thinking this document cites Theodore Ratisbonne's complaint about the lack of welcome often demonstrated to Jewish converts. Accordingly, the Sisters of Sion are to create an atmosphere of unreserved welcome. ${ }^{140}$

The document recommends various strategies for this. In religious education, Sisters should provide biblical instruction highlighting the election of the Jewish people, their religious ideals and the greatness of their saints, both biblical and contemporary. Attention should be paid to presenting correctly the role of the Jews in the passion and death of Jesus. With the Tridentine Catechism, the Chapter document identifies the sins of all as causing the death of Jesus. It notes that "if certain Jews and certain pagans were historically our representatives, the re-

\footnotetext{
${ }^{136}$ In 1969 , the centre took the name SIDIC-Paris, with "SIDIC" standing as an acronym for Service Internationale de Documentation Judéo-Chrétienne.

${ }^{137}$ Gros, "La Congrégation," 491.

${ }^{138}$ Marx, Les relations, 310.

${ }^{139}$ XVI Chapître Général, 1957, Feuille No. 7, "Israël I. Fondement théologique de la mission pour Israël d'après Notre Père," Série 1 G 17, "Chapitre general, 1957," Archives Notre-Dame de Sion, Paris.

${ }^{140}$ XVI Chapître Général, 1957, Feuille No. 8, “Israël II. Notre apostolat en faveur d'Israël,” p. 1, 1 G

17, General chapter of 1957, Archives de Notre-Dame de Sion, Paris.
} 
sponsibility that God alone knows and judges, cannot in any way be attributed to Jews of all times." 141

The document recommends how to deal with Christian antisemitism, observing that it is necessary to eliminate one by one the factors that can give rise to it: religious themes like deicide and the divine curse; historical themes such as ritual murder and the Protocols of the Elders of Zion; economic and social themes like Freemasonry. ${ }^{142}$ It also excerpts from the writings of several scholars to help the sisters prepare to confront these issues. Elsewhere, the document develops some of those ideas and strategies, urging sisters to come to know Israel, to stand in solidarity with the Jewish people, and to become cognizant of the commonalities between Christian and Jewish traditions. Yet one still finds references to conversion, like, "...before all else, our duty is a duty of prayer. It is the only activity adequate to its object. Conversion is not, in effect, a human work but a divine work." 143

The sisters' thinking continued to develop all through the 1950s. Israël et Nous became a vehicle where sisters and others published articles on Judaism, both their own work as well as summaries and reprints of other scholars' material. Paul Démann and Géza Vermès, as well as Kurt Hruby, also developed their understandings of the covenant in contemporary Judaism, the place of prayer in Judaism, Hasidism and Jewish mysticism. ${ }^{144}$ Like the scholarly Cahiers Sioniens, Israël et Nous also addressed questions around the newly established state of Israel. ${ }^{145}$ During this period, however, overwhelming absorption in the task of education that was the primary ministry of most of the sisters meant that questions concerning the relationship of Judaism and Christianity remained a matter for a rather small group of sisters, in spite of the chapter's call and despite the fact that Israël et Nous was available in all the communities of the Congregation. ${ }^{146}$

To animate the work of the various centers and facilitate the formation of the whole Congregation in Bible and Jewish studies, Mother Marie-Félix organized training for sisters she deemed suitable. Some sisters would follow the programs of the Paris center without getting further degrees, while others would pursue doctoral programs in areas related to theology, like Bible and Jewish history. ${ }^{147}$ In 1955, Sr. Aline defended her doctoral thesis at the Sorbonne, on the Fortress Antonia. In 1957 Mother Marie-Félix sent Sr. Marie-Bénédicte Salmon to Lyon for a licentiate in religious education. In 1958, Sr. Georgine became the first Sister of Sion to study at Hebrew University.

\footnotetext{
${ }^{141}$ XVI Chapître Général, 1957, Feuille No. 8, p. 2, citing Paul Démann, "Les Juifs dans la catéchèse chrétienne," Cahiers Sioniens (1952). The page reference is missing. For the text cited from the Catechism of the Council of Trent (1566), article 4, paragraphs 597-598, see http://www.vatican.va/archive/ccc css/archive/catechism/p122a4p2.htm (accessed Oct. 22, 2016).

${ }_{142}$ XVI Chapitre Général 1957, Feuille No. 8, pp. 5-6.

143 E.g., XVI Chapitre Général 1957, Feuille No. 9, "Israël: notre apostolate en faveur d'Israël, (suite)," p. 3, G 17, General chapter of 1957, Archives de Notre-Dame de Sion, Paris .

${ }^{144}$ Marx, Les relations, 314.

${ }^{145}$ Marx, Les relations, 315.

${ }^{146}$ Delpech, "Notre Dame de Sion et les Juifs," 371; Marx, Les relations, 311.

${ }^{147}$ Marx, Les relations, 312-313. Theological degrees, per se, were not available for women yet.
} 
The very practical decisions and projects initiated by Mother Marie-Félix and her colleagues, especially in the wake of l'Affaire Finaly were showing results. Things were not, however, moving quickly enough as would become clear in two letters Mother Marie-Félix wrote on July 2, 1961 and August 15, 1962. In June of 1961she had gone to Rome to discuss the canonical status of the Ancelles with Archbishop, later Cardinal, Paul Philippe, Secretary for the Sacred Congregation of Religious. In the first letter, addressed to the provincials and vice-provincials of the Congregation, ${ }^{148}$ she reports that Philippe turned the subject to the ministry of the entire Congregation, focusing not on the Ancelles, but on those sisters engaged primarily in education. Mother Félix reported that the cardinal challenged the Congregation, as the only religious order in the Church dedicated to the Jewish people, to focus more clearly on its specific vocation. She summarized his thinking, saying that he had noted that, while sisters prayed a great deal for Israel, they did not go often enough to encounter Jewish people. He felt that for the Ancelles to be the specialists in this "direct apostolate" was to deprive the whole Congregation of its raison d'être. He believed that, without neglecting the ministry of education, more sisters should be trained for the kind of "direct ministry" so often assigned to the Ancelles. Moreover, the cardinal emphasized that the usual conditions of cloister, religious habit, daily schedule should all be adapted in the measure necessary to accommodate such encounter. Sisters should think about professional commitments that would both facilitate and make such contacts more effective. ${ }^{149}$

The following year, on August 15, 1962, Mother Félix wrote to the superiors of the houses in France. She set her remarks in the social and political contexts of the countries in which the Congregation's communities were located, including Israel. War, social and political upheaval, oppression and totalitarianism - these were Sion's realities, just as they were the realities of the world at large. Mother Marie-Félix notes the approaching opening of the Second Vatican Council, and cites John XXIII's exhortation calling members of religious orders fully to participate in the Church's renewal. ${ }^{150}$

The opening pages of Mother Marie-Félix's nine-page letter consequently call for this response:

The world is changing. It needs us to speak a language that it can understand. It must see the face of Christ through us. What can we do together for this, in this year of the ecumenical council? Before a world that is changing, the

\footnotetext{
${ }^{148}$ Lettre de Mère Marie-Félix aux Reverendes Mères Provinciales et Vice-Provinciales de la Congrégation, 2 juillet 1961, 3 G 3, Circulars from the general superior 1931-1975, Archives Notre-Dame de Sion, Paris. Provincials and vice-provincials were superiors of geographical regions, whether one country or several. The difference in terminology designates the relative size of the region for which they were responsible.

${ }^{149}$ Mother Marie-Félix, Lettre aux Rev. Mères provinciales et vice-provinciales de la Congrégation, 2 juillet 1961 .

${ }^{150}$ Mother Marie-Félix, Lettre aux mères supérieures de la France, 15 août 1962, p. 3 , 3 G 3, Circulars from the superior general 1931-1975, Archives Notre-Dame de Sion, Paris. Cf. John XXIII, "Il Tiempo Massimo,” July 2, 1962, Acta Apostolicis Sedis 54(1962): 508-517.
} 
Congregation cannot remain with apostolic solutions made for a social situation and mentality that is in the process of disappearing. ${ }^{151}$

She indicates that in its upcoming general chapter, Sion will need to examine new ways of approaching the task with which the Congregation has been charged, its mission of love for Israel ("mission d'amour envers Israël"). It will need to answer Cardinal Philippe's challenge to realize its mission "not only by prayer and the offering of our religious life, but still more by a precise knowledge of Israel (une connaissance d'Israël exacte) leading to concrete action."152

Until this point, the development of the Congregation's thinking had been significant but slow. August 15, the date of this letter, was the customary day for publishing changes to sisters' place of residence and ministerial assignments and Mother Félix announced concrete, even dramatic, changes that affected the whole Congregation: efforts to educate increasing numbers of sisters in Scripture, theology and Jewish studies and to reinforce personnel in study centers and in Israel. These represented real changes in the Congregation's institutional commitments. Mother Félix announced the closure of three communities with large and flourishing schools, two in France (Biarritz and Le Mans) and one in Brazil (Belo Horizonte), to allow the Congregation to reinforce its study center in Paris and its house in Ein Karem. This impacted hundreds of lives - not only of the transferred sisters, but also of children, parents and colleagues. The house of study in Paris would welcome sisters from other provinces. A study center for Jewish-Christian relations would develop in London, and the Canadian province would send sisters for graduate studies in theology. The house in Belo Horizonte (Brazil), would be closed in order to establish a house of study in São Paulo. Neither letter alludes to the conversion of the Jews. Cardinal Philippe speaks of "encounter," and Mother Félix uses language that seems to continue the tone of "rapprochement" signaled in her letter of 1951.

This is the context in which the sisters became directly involved in the writing of Nostra Aetate. It also explains why some sisters still needed to internalize the changes. On May 6, 1963, three days after Sr. Marie-Bénédicte began her series of visits to French bishops and theologians about the writing of Nostra Aetate, Mother Marie-Félix wrote to the whole Congregation to announce the convocation of its seventeenth general chapter, eventually delayed a month until January of 1964. The general council sent to all the delegates, under Mother Marie-Félix's name, a report of its governance and its assessment of the Congregation's situation.

That report states that there remains a great deal of work to be done in the integration of the Congregation's vocation in relation to the Jewish people. It still refers to "the sanctification of Israel," but makes no mention of conversion. It voices a concern that Sion's traditional prayers reflect $19^{\text {th }}$ century "anti-Judaism" which the report calls "anti-Semitism." These require revision because the men-

\footnotetext{
${ }^{151}$ Lettre, 15 août 1962 , p. 3

152 Lettre, 15 août, p. 4.
} 
tality they express actually blocks the Sisters' knowledge of the Jewish people and witness of love toward them. ${ }^{153}$ The report calls for a more biblical spirituality, one coherent with the current biblical and liturgical renewal and grounded in an understanding of the implications of all forms of prejudice, including those enabling the Nazi persecution. This text also acknowledges the importance of the State of Israel for the Jewish people: "The State of Israel has been born and allows liberated Jews to find themselves once again in their own land and gives spiritual liberation to Jews living in other countries." 154 The context for this new thinking is explicitly the ecumenism that is at the heart of the Second Vatican Council, and which calls for "understanding, dialogue, [and] friendship with those who do not share our religious faith.,"155

Cardinal Bea addressed the chapter delegates during their deliberations on January 15,1964 . It was but a few weeks since he had presented the first draft of a document on the Jewish people to the Council. ${ }^{156}$ He would speak again on Nov. 3, 1965, a few days after the promulgation of Nostra Aetate, telling Sisters, gathered for another meeting, that Nostra Aetate is "a real program for your work" ("un vrai programme pour votre travail"). He encouraged them:

...do not be afraid if the road to follow is not always clear. In such a new field of action it cannot be expected that all should be clear. I can tell you that in our Secretariat we have had, and still have, the same difficulty; as a matter of fact, our work was so new that we could not even plan ahead. ${ }^{157}$

The 1964 chapter document reflects a new sensibility. Delegates call for an ecumenical attitude vis-à-vis Jewish people (cette attitude oecuménique vis-à-vis des Juifs). This means an acceptance of Jews as they are, an openness to perceive their religious values. Two paragraphs are worth quoting in full:

This ecumenical attitude in relation to the Jews consists in acknowledging them and accepting them as different from ourselves, in perceiving the real though incomplete religious values that they possess, to see them engaged with us in the Mystery of Salvation that unfolds through time. This Mystery

\footnotetext{
${ }^{153}$ Compte-rendu du gouvernement general aux capitulaires pour le XVIIème chapître general de la Congrégation de Notre-Dame de Sion, Rome, janvier 1964, pp 13-14, 1 G 18, "General chapter of 1964, preparation," Archives Notre-Dame de Sion, Paris.

${ }^{154}$ Compte-rendu ... pour le XVIIème chapître, p. 14; "L'État d'Israël est né et permet aux Juifs libérés de se retrouver eux-mêmes sur leur terre et libère spirituellement les Juifs vivant sur les autres contrées du globe." It is unclear whether "Juifs libérés" refers to Jews freed from Nazi and British camps, or whether it is a metaphorical reference to the reality of the restoration of the Jewish homeland.

${ }^{155}$ Compte-rendu ... pour le XVIIème chapître, p. 14.

156 “Aux religieuses de N.D. de Sion," January 15, 1964, no number, Archives Notre-Dame de Sion, Paris.

157 "Nouveau message de S.Em. le Cardinal Béa aux Religieuses de N.D. de Sion," November 13, 1965, Rome; no number, Archives Notre-Dame de Sion, Paris. See also his similar 1966 talk, "H.E. Cardinal Bea's talk to the Religious of Our Lady of Sion," November 3, 1966, Rome; no number, Archives Notre-Dame de Sion, Paris.
} 
is in the hands of God whose call and gifts are "without repentance." 158 As for us, we must do everything that depends on us to "break down the wall of separation" $" 159$ without seeking to "make converts."

The true ecumenical attitude continues to desire the reunion of Jews and Christians, but when and how God wants. It wishes, certainly, that we witness by our life to salvation in Christ, and that we be ready to respond about our faith to any who ask us to give an account. But the ecumenical attitude dismisses resolutely all proselytism as contrary to the spirit of the Church and also to the deep inspiration of Our Father [the traditional title given to Sion's founder, Theodore Ratisbonne]. Proselytism, indeed, seeks to convert without respecting the mysterious action of God who alone knows what is best for each soul. ${ }^{160}$

The text is not without problems, such as the phrase "real though incomplete religious values." But it represents a move forward in Christian thinking in speaking of an ultimate reunion of Jews and Christians in ways unknown to us, with no allusion to conversion except in eschewing all forms of proselytism. That eschatological note will find further expression in later Church documents as Catholics continue to struggle over the seeming contradictions present in the desire to turn aside from the quest for conversions that had proven so destructive for centuries, and the need to articulate new modes of reflection on questions of the Church's relationship to the Jewish people, as well as the internal questions of Christology and ecclesiology that would allow theological "space" for Judaism as a continuing reality. ${ }^{161}$

The 1964 general chapter document continued to recognize the need for the Sisters of Sion to know the Jewish people. Reference to the Shoah as well as to

\footnotetext{
${ }^{158}$ Here Cardinal Bea references Rom 11:29.

${ }^{159}$ Bea alludes here to Eph 2:14.

${ }^{160}$ Comte-Rendu de XVIIème Chapître General 1-22 janvier 1964, Cinquième Dossier: "Israël: Notre Mission d'Église," p. 34, 1 G 18, General Chapter of 1964, Archives Notre-Dame de Sion, Paris . "Cette attitude oecuménique vis-à-vis des Juifs consiste à les reconnaître et à les accepter differents de nous, à percevoir les valeurs religieuses incomplètes, mais réelles qu'ils possèdent, à les voir engagés avec nous dans le Mystère du Salut qui se déploie dans le temps. Ce Mystère est entre les mains de Dieu, dont l'appel et les Dons [sic] sont 'sans répentance'. Nous, nous devons faire tout ce qui dépend de nous pour 'saper le mur de séparation', sans chercher à 'faire des conversions'. Le véritable attitude oecuménique continue à desirer la réunion des Juifs et des Chrétiens, mais quand et comme Dieu la voudra. Elle veut, certes, que nous témoignions par notre vie du Salut dans le Christ, et que nous soyons prêtes à répondre de notre foi à tous ceux qui nous en demandent compte. Mais elle écarte résolument tout prosélytisme, comme contraire à l'esprit de lÉglise et aussi à l'inspiration profonde de Notre Père. Le prosélytisme, en effet, cherche à convertir sans respecter la conduit mystérieuse de Dieu: Celui-ci seul sait ce qui est le meilleur pour chaque âme."

${ }^{161}$ See the most recent document of the Commission for Religious Relations with the Jews, "'The Gifts and the Calling of God are Irrevocable' (Rm 11.29): a Reflection on Theological Questions Pertaining to Catholic-Jewish Relations on the Occasion of the $50^{\text {th }}$ Anniversary of 'Nostra Aetate'(No. 4)," especially paragraphs $36-40$; http://www.vatican.va/roman_curia/pontifical councils/chrstuni/relations-jewsdocs/rc pc chrstuni doc 20151210 ebraismo-nostra-aetate en.html.
} 
the actuality of the State of Israel lent a sense of contemporary realities, and gave a concrete framework to what it might mean to "know the Jewish people." Furthermore, there was a new sense of mutuality; the text not only expresses the desire to know the religious ideals of Judaism, but to learn from them. Perhaps most important, there was a desire to be in friendship with Jews "as far as God allows, ... through personal relationships. (Nous voulons, autant que Dieu le permet, être en amitié avec eux par des relations personnelles...)" 162

Concrete decisions included accepting the recommendations of the previous general council to revise the Congregation's public prayers to bring them into line with this ecumenical understanding of Sion's vocation. ${ }^{163}$ However, no new works were undertaken immediately. Rather, there was a deepened understanding of the task, a new sense of vigor lent by the authorization of the Council's work, and the encouragement of Church authorities.

\section{Conclusions}

How did this group of French women religious transform their mission to the Jews from conversion to dialogue? What was happening in their Congregation and in the broader religious and intellectual circles of French theological development that fostered such a project? The efforts of the Sisters of Sion during the Second Vatican Council had a long pre-history. They inherited philosemitism, with its possibilities for new ways of thinking about Jewish-Christian relations, grounded in decades of friendships between those engaged in the conversation. The work of Sion was nurtured by ressourcement, whose emphasis on "return to the sources" in rearticulating faith in relation to the contemporary world enhanced the Congregation's own tradition of biblical study and attention to Jewish and Christian sources. The aftermath of the Shoah also challenged Christian understandings of Judaism, and of the relationship of the Church to the Jewish people. Furthermore, the development that allowed the Sisters of Sion to make their particular contribution was a direct result of l'Affaire Finaly, and the ensuing scandal that laid bare the fault lines of previous ways of thinking. This was a decadeslong journey, carried out against the backdrop of war, social and political upheaval, the tragedy of the Shoah and the rebirth of the State of Israel. It was also a journey of friendship of sisters with one another and with the Fathers of Sion, with collaborators and friends, Jews, Catholics, Protestants and Orthodox, lay and clergy. It is a never-ending journey, and in subsequent decades, the sisters have continued to attend to the challenge of a vocation that calls them to "stand beside both the Israeli and Palestinian peoples in their suffering." In a world filled with hatred, their vocation calls them to be "women of dialogue in the JewishChristian relationship," while reading Nostra Aetate "in its entirety" and entering

\footnotetext{
${ }^{162}$ Compte Rendu du XVIlième Chapître Général, Cinquième Dossier "Israel: Notre Mission d'Église," p. 35.

163 Compte Rendu du XVIIième Chapître Général, Cinquième Dossier "Israel: Notre Mission d’Église," p. 35.
} 
more intentionally into relationship with people of other faiths, especially Muslims, in the quest for justice and in care for the earth. ${ }^{164}$

${ }^{164}$ Report of the $25^{\text {th }}$ General Chapter of the Congregation, July 2010, "Charism," Series 1 G 51, General Chapter of 2010, Archives de Notre-Dame de Sion, Paris. 